\title{
The Role of IT Application Orchestration Capability in Improving
}

\section{Agility and Performance}

\author{
Magno Queiroz (Corresponding Author) \\ Jon M. Huntsman School of Business \\ Utah State University, USA \\ magno.queiroz@usu.edu \\ Paul P. Tallon \\ Sellinger School of Business \\ Loyola University Maryland, USA \\ pptallon@loyola.edu \\ Rajeev Sharma \\ Waikato Management School \\ The University of Waikato, New Zealand \\ rsharma@waikato.ac.nz \\ Tim Coltman \\ Waikato Management School \\ The University of Waikato, New Zealand \\ tcoltman@waikato.ac.nz
}

\begin{abstract}
This paper investigates how IT application orchestration - a dynamic capability encapsulating a firm's ability to refresh its application portfolio through a process of building, buying, and retiring IT applications - impacts firm performance. We propose a conceptual model in which the effect of IT application orchestration on firm performance is mediated by process agility. We further propose that a firm's strategic orientation moderates the effect of IT application orchestration capability on process agility. Analysis of data from an international survey of IT executives supports our proposed hypotheses. This research contributes to the emergent literature on dynamic capabilities by proposing and testing a theory of how IT application orchestration capability affects agility and firm performance.
\end{abstract}

Accepted at Journal of Strategic Information Systems. Available online at https://doi.org/10.1016/j.jsis.2017.10.002 


\section{Introduction}

In the first decade of the new millennium, the relationship between information technology (IT) and process agility has emerged as a key area of interest for IT executives (Luftman et al. 2013; Roberts and Grover 2012). ${ }^{1}$ In response, academics have begun to explore the effects of IT resources and capabilities on process agility (agility, for brevity) and the resulting implications for firm performance (Chen et al. 2014; Tallon and Pinsonneault 2011). The link between agility - defined as "the ability to detect and respond to opportunities and threats with ease, speed, and dexterity" (Tallon and Pinsonneault 2011, p. 464) - and firm performance underlines the need for businesses to adapt quickly to new market conditions and the risks from failing to react in time (Chakravarty et al. 2013; Ravichandran 2017; Sambamurthy et al. 2003). Calls for IT-based responses to market change require that IT resources be continuously and quickly updated (Vessey and Ward 2013; Weill et al. 2002). This might involve retiring legacy systems that impede agility or extending the IT portfolio with new agility-enabling applications (Boh and Yellin 2007; Clark et al. 1997). This, in turn, triggers discussions on the type of capabilities required to manage an evolving IT portfolio and whether firms should build or buy IT (Leiblein et al. 2002; Rai et al. 2015). While research shows that IT can improve agility (Chen et al. 2014; Roberts and Grover 2012), the literature is relatively silent on how firms should manage their IT resources to deliver greater agility, the capabilities needed to do this, and the resulting implications for firm performance.

Studies show that a wide variety of IT-related capabilities, including information management capabilities, IT infrastructure capabilities, and planning capabilities, generate performance benefits for firms (Lu and Ramamurthy 2011; Mithas et al. 2011; Pavlou and El Sawy 2011; Rai et al. 2006; Rai and Tang 2010). Studies also show that agility is an important mechanism through which IT capabilities affect firm performance (Chen et al. 2014; Ravichandran 2017). Despite significant advances in that literature, the focus of prior studies has been primarily on IT infrastructure and planning. In contrast, less attention has been paid to IT applications-related capabilities and how firms generate benefits from their IT

\footnotetext{
${ }^{1}$ Since the great recession in 2008 , agility has been repeatedly ranked as a top ten concern for IT executives (Luftman et al. 2013).
} 
application portfolios (Nazir and Pinsonneault 2012). While IT infrastructure is becoming more of a commodity (Bhatt and Grover 2005), firms are increasingly investing in applications such as analytics and business intelligence, business process management, and intrafirm collaborative systems in the hope of increasing agility and performance (Kappelman et al. 2016; Luftman et al. 2012, 2013; Nazir and Pinsonneault 2012). However, we know little about whether and how a firm's capacity to update its IT applications portfolio affects agility and how agility, in turn, affects firm performance.

This study extends prior research by investigating the effects on agility and performance of a firm's ability to renew its portfolio of IT applications. We refer to this capability as IT application orchestration. Teece (2007) posits that the ability to renew a portfolio of resources is an important orchestration capability that can generate significant benefits for firms. ${ }^{2}$ Sirmon et al. $(2007,2011)$ further explain that resources tend to lose their value rapidly because of market changes and, therefore, firms need to continuously and quickly add new resources to their portfolios (i.e., purchase and develop new resources while divesting less-valuable ones). Like any other portfolio of resources, the IT applications portfolio must be continuously updated; firms do so by purchasing new applications, building applications, and discontinuing those that are no longer relevant. Hence, we define IT application orchestration capability as the ability of firms to renew the IT applications portfolio through developing IT applications, purchasing IT applications, and discontinuing less-relevant ones. Drawing on the above literature and prior studies on IT capabilities, we build and test a model of how IT application orchestration capability affects agility and firm performance.

This paper contributes to the literature in two respects. First, we show that IT application orchestration capability generates performance benefits and that agility is a key mechanism through which these benefits occur. Second, we show that strategic orientation moderates the effect of IT application orchestration capability on agility. Specifically, the effects of IT application orchestration

\footnotetext{
2 This is often described in the strategic management literature as "asset orchestration" (Teece 2007). We use the term "resources" instead of "assets" to be consistent with IS research that defines IT capability in terms of resources (Bharadwaj 2000) and that defines resources as profit-producing assets (Drnevich and Croson 2013).
} 
capability on agility are stronger in firms pursuing a strategy of differentiation rather than operational excellence. We assessed these relationships at the business unit level within a broader firm context and so our findings must be interpreted in that more restrictive domain.

The rest of this paper is organized as follows. The next section discusses prior literature on IT capability and orchestration capability and develops our hypotheses. Then, we outline the data collection approach, the measures employed in this study, and the analysis conducted on the empirical data. The subsequent section presents the study results. Finally, we evaluate the results, analyze research limitations, and discuss the implications of the research for theory and practice.

\section{Theoretical Background}

\section{Prior Research on IT Capability and Orchestration Dynamic Capability}

IT capability refers to an organization's "ability to mobilize and deploy IT-based resources in combination or copresent with other resources and capabilities" (Bharadwaj 2000, p. 171). Prior literature investigates various dimensions of IT capability. For instance, Weill and Vitale (2002) and Weill et al. (2002) examine IT infrastructure capability and infrastructure services, including security and risk management, communication, data management, application infrastructure, IT facilities management, and IT architecture and standards; Bharadwaj (2000) focuses on human IT resources, IT infrastructure, and IT-enabled intangibles; Fink and Neumann (2007) investigate IT personal and IT infrastructure capabilities; and Wang et al. (2012) examine IT planning and use. The empirical evidence in this body of literature shows that IT capabilities are important enablers of firm performance. A summary of the literature examining the performance impacts of IT capabilities is provided in Appendix A.

A number of studies have argued that the primary effects of IT occur at the process-level and that those effects may aggregate to the firm-level (Barua et al. 1995; Melville et al. 2004; Mithas et al. 2011; Setia et al. 2008; Tallon 2008). This suggests that process-level impacts of IT are important for understanding how IT capabilities relate to firm performance. For example, Ray et al. (2005) and Setia et al. (2013) show that IT capabilities affect business 
process performance. Fink and Neumann (2007), Lu and Ramamurthy (2011), and Chen et al. (2014) show that IT capabilities enhance process agility which, in turn, affects firm performance (Chen et al. 2014; Tallon and Pinsonneault 2011).

Consistent with the argument that the primary effects of IT occur at the process-level, Pavlou and El Sawy $(2006,2011)$ investigate the impacts of IT capabilities on the new product development (NPD) process. They show that competitive advantage in NPD depends on IT-enabled dynamic capabilities and functional competencies. This is an important area of research for understanding the performance impacts of IT because, while a number of studies investigate IT functional competences (e.g., Bharadwaj 2000; Chae et al. 2014; Chen et al. 2014; Fink and Neumann 2007; Wang et al. 2012; Weill et al. 2002), less attention has been paid to IT-enabled dynamic capabilities that are more likely to enable differentiation strategies (Koch 2010; Pavlou and El Sawy 2011; Roberts and Grover 2012). For instance, we know little about how IT-enabled dynamic capabilities impact process-level outcomes such as process agility.

Two managerial competences are core to dynamic capabilities: search and selection, and asset/resource orchestration (Helfat et al. 2007). Search and selection involve the identification of opportunities and formulation of actions, including allocation of resources. Orchestration focuses on the assembling and structuring/re-structuring of the resource base (Helfat et al. 2007; Sirmon et al. 2011; Teece 2007). The dynamic capabilities theory argues that the identification of opportunities and formulation of actions are necessary to achieve competitive advantage and improved firm performance (Helfat et al. 2007; Pavlou and El Sawy 2011; Sirmon et al. 2011; Teece 2007; Teece et al. 1997). However, significant performance gains are likely to occur through orchestrating organizational resources (Helfat et al. 2007; Sirmon et al. 2011; Teece 2007). This requires continuous efforts to build, maintain, and adjust the resource base to address rapidly changing market conditions (Teece 2007). Resource orchestration is a promising area of investigation to understand how firms derive benefits from their resources (Sirmon and Hitt 2009; Teece 2007) or from IT more specifically (Sharma and Shanks 2011; Wang et al. 2012). 
The discussion above suggests two opportunities for extending prior research. First, existing literature focuses on functional competences, specifically, IT infrastructure and related management capabilities. At the same time, IT infrastructure is becoming more of a commodity and IT applications that enable differentiation tend to lose their value quickly because of market changes, an increase in the pace of IT innovation, and the shrinking of IT applications' lifecycle (Rettig 2007; Ross et al. 2006; Vessey and Ward 2013). Realizing IT benefits under these conditions requires continuous efforts to build and maintain the IT applications portfolio. This is illustrated by surveys of IT executives that find IT applications such as business intelligence, data management, business process management, and new interfirm and intrafirm collaborative systems are key priorities for firms seeking to adapt to market discontinuities (Kappelman et al. 2016; Luftman et al. 2012, 2013). Previous studies show that orchestration of resources is an important dynamic capability for adapting to changing market conditions and for improving firm performance (Sirmon and Hitt 2009; Sirmon et al. 2007; Teece 2007; Wang et al. 2012). Drawing on that literature, we propose that during periods of continuous and often rapid market change, the ability of firms to renew their IT application portfolios is an important driver of firm performance.

Second, IT capability impacts performance through intermediate process-level outcomes such as agility and business process efficiency (Chen et al. 2014; Karimi et al. 2007; Lu and Ramamurthy 2011; Roberts and Grover 2012). However, our knowledge of the underlying mechanisms through which IT capabilities affect performance is still limited (Mithas et al. 2011). For example, we know little about how IT orchestration capabilities affect agility and the resulting implications for firm performance. It is equally unclear how differences in firms' strategic orientations affect the relationship between IT orchestration capabilities and performance outcomes (Aral and Weill 2007; Sabherwal and Chan 2001; Weill and Broadbent 1998). We contend that these are important issues for understanding the performance effects of IT application orchestration capability. 


\section{Conceptualizing IT Application Orchestration Capability}

IT application orchestration capability concerns the ability of firms to renew their IT application portfolios. In line with prior research (Nazir and Pinsonneault 2012; Weill and Vitale 1999), we consider an IT application portfolio as comprising the bulk of applications a firm uses to support its business processes. ${ }^{3}$ Hence, firms with IT application orchestration capabilities are better able to renew the portfolio of IT applications used to support various business processes such as sales, supplier relationship management, marketing, and customer relations. IT applications, like other organizational resources, are "profit-producing assets" that can generate strategic benefits (Drnevich and Croson 2013, p. 485) but their strategic potential depends on whether they are valuable, rare, inimitable, and non-substitutable (Nevo and Wade 2010). Even when a firm is able to replicate an IT application used by a competitor, the firm is unlikely to completely replicate a portfolio of IT applications that is continuously being updated. This is in line with Ndofor et al. (2011) who argue that the rarity of a firm's overall portfolio of IT resources will be greater than the rarity of any individual element of that portfolio. It is also in line with Tallon et al. (2016) who argue that a firm's ability to achieve competitive advantage depends on how its IT resources support those business processes that are critical to the firm's goals.

Our conceptualization of IT application orchestration capability is grounded in Sirmon et al.'s $(2007,2011)$ research on resource management and extant literature on IT capabilities (Lee and Xia 2010; Van Oosterhout et al. 2006; Vessey and Ward 2013). Sirmon et al. (2007) emphasize the need for firms to continuously and quickly update their resource portfolios. They identify three distinct competencies through which firms can update their resource base: acquiring resources from factor markets, developing resources internally, and divesting firm-controlled resources. Other studies suggest that firms can update their IT resource base through acquiring, developing, and divesting IT resources. For example, Tanriverdi (2006) argues that firms should build relationships with IT vendors for sourcing IT and negotiating terms

\footnotetext{
${ }^{3}$ Weill and Vitale (1999) argue that an individual IT application can focus either on minimizing cost, driving economies of scale or increasing product quality and, as such, firms invest in different types of applications to build a healthy IT portfolio that can support all of their core business processes.
} 
of contracts, thus enhancing their ability to acquire valuable IT resources. Vidgen and Wang (2009) and Lee and Xia (2010) argue that firms should also be able to develop IT applications internally to cope with rapidly changing business conditions. They propose that agile software development approaches can speed up the development of new applications. In addition, firms should identify and discontinue inflexible legacy systems as they can increase IT complexity, create rigidities, and undermine agility (Van Oosterhout et al. 2006). Our conceptualization of IT application orchestration capability takes into account these key competencies, namely developing IT applications internally, purchasing IT applications externally, and discontinuing other applications that have reached the end of their useful life.

The competencies that underline a capability are patterns of actions that constitute organizational skills (Augier and Teece 2008; Eisenhardt and Martin 2000; Teece et al. 1997; Winter 2000). They can be repeated reliably over time and across different organizational activities (Eggers and Kaplan 2013; Winter 2000). For example, a firm with IT application orchestration capability possesses the skills to develop IT applications internally. It may use that capability to develop standalone IT applications or to build new modules for existing applications. Hence, firms benefit from IT application orchestration capability when there is a need to make changes - either incremental or discontinuous - to their IT application portfolios.

\section{Conceptual Model and Hypotheses}

Our research model and hypotheses are shown in Figure 1. The core idea underlying our model is that the ability of firms to renew their IT application portfolios is an important enabler of agility and, in turn, firm performance. Specifically, firms can improve agility when they integrate new applications into their IT portfolios and when they are able to discontinue legacy systems that create rigidities (Bhatt and Grover 2005; Lu and Ramamurthy 2011; Nazir and Pinsonneault 2012). In addition, firms pursuing different strategic orientations generate different benefits from IT resources and capabilities (Aral and Weill 2007; Sabherwal and Chan 2001; Tallon 2008; Weill and Broadbent 1998). Hence, the effects of IT application orchestration capability can vary as a function of the strategic orientation of firms. Our theory proposes that IT application orchestration capability affects agility and that strategic orientation 
moderates this effect (H1 and H2 in Figure 1). Drawing on research that argues that agility affects firm performance (Chakravarty et al. 2013; Chen et al. 2014; Lu and Ramamurthy 2011; Tallon and Pinsonneault 2011), we also postulate that IT application orchestration capability indirectly enhances firm performance through agility (H3 in Figure 1). We develop these hypotheses in greater depth in the following sections.

Figure 1. Research Model

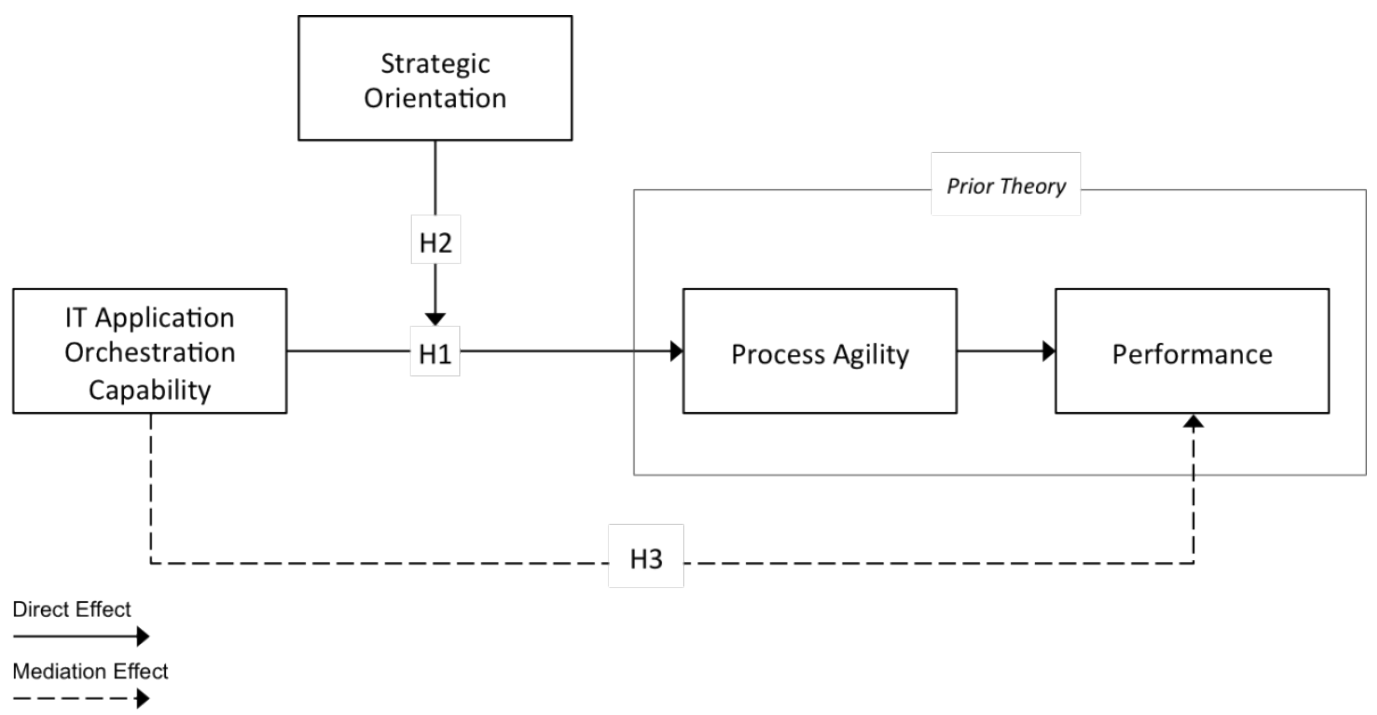

\section{IT Application Orchestration Capability and Agility}

IT-enabled dynamic capabilities help firms identify and implement new IT initiatives to ensure that IT resources are current with the needs of business processes (Pavlou and El Sawy 2006, 2011). Business processes refer to "actions that firms engage in to accomplish some business purpose or objective" (Ray et al. 2004, p. 24). Therefore, they can be thought of as routines that organizations develop to succeed in the marketplace (Teece et al. 1997). As firms embed IT within organizational routines (Ray et al. 2005; Tallon 2008; Wang et al. 2012), business processes become more dependent on IT resources and the frequency with which their IT needs change increases (Broadbent et al. 1999; Newkirk et al. 2008; Vessey and Ward 2013). This suggests that renewing the IT resource base is a key mechanism through which firms ensure the execution of their business processes. For example, the IT demands of the customer relations process change regularly, requiring firms to invest in new customer 
relationship management (CRM) applications and to divest existing IT solutions that are not generating sufficient benefits (Coltman 2007; Goodhue et al. 2002; Ray et al. 2005). For instance, the Danish food ingredients conglomerate Danisco developed a modular CRM application suite in-house to support its growth-by-acquisition strategy and to allow it to more easily absorb fluctuations in customer demand (Yetton et al. 2013). Similarly, in order to meet the changing IT needs of other core processes such as product enhancement and marketing, firms often purchase and develop new IT applications such as data management and market intelligence (Chen et al. 2012; Germann et al. 2013). This underscores the fact that valuable resources such as IT can become core rigidities if they are not modified or altered to meet evolving business needs (Ambrosini et al. 2009; Leonard-Barton 1992).

Moreover, research on the effects of IT on agility argues that firms should continuously sense market-based threats and opportunities and act quickly to respond to those threats and opportunities (Chen et al. 2014; Lu and Ramamurthy 2011; Nazir and Pinsonneault 2012; Overby et al. 2006; Roberts and Grover 2012; Sambamurthy et al. 2003; Tallon and Pinsonneault 2011). It follows that changes to the IT resource base often result from a firm's attempts to adapt to new market conditions and exploit opportunities that these market conditions offer (Van Oosterhout et al. 2006). Thus, firms failing to renew their IT applications are potentially less capable of responding quickly to changing market conditions. For example, legacy IT applications are usually difficult to change. They increase IT complexity and make it difficult for firms to integrate new applications into their IT portfolios, thereby hurting agility (Lu and Ramamurthy 2011; Nazir and Pinsonneault 2012; Van Oosterhout et al. 2006). The case of Cisco Systems is illustrative. Cisco was undergoing rapid growth in the 1990s but its legacy IT applications were not robust or flexible enough to support the firm's changing IT needs. After experiencing a series of failures in its legacy IT applications, Cisco's CIO decided to give line managers more autonomy to identify and propose solutions to IT issues affecting them. The strategy did not work, however. Despite limited agility due to inflexible legacy IT, none of the line managers stepped forward to suggest a project. After a year the legacy systems failed catastrophically, shutting down the company for two days, eventually leading to 
the purchase and implementation of a new global ERP system (McAfee 2003). The key takeaway is that agility depends not only on the ability of firms to quickly build or buy IT applications but also on their ability to act rapidly to discontinue inflexible applications that are creating rigidities. IT application orchestration capability is a key mechanism through which firms enable IT-based responses to market changes (e.g., by adding new applications to the IT portfolio) and eliminate barriers to agility (e.g., by divesting legacy applications). Hence, we hypothesize the following:

\section{H1: IT application orchestration capability has a positive effect on agility.}

\section{Moderating Role of Strategic Orientation}

Firms pursuing different strategic orientations utilize IT resources in different ways (Tallon 2008; Treacy and Wiersema 1995). Also, they do not realize the same benefits from IT (Aral and Weill 2007; Drnevich and Croson 2013; Sabherwal and Chan 2001; Tallon 2008; Weill and Broadbent 1998). For example, Tallon (2008) finds that firms pursuing a strategy of differentiation through customer intimacy or product leadership improve performance when they use IT resources to enable core value chain processes. In contrast, firms pursuing operational excellence (i.e., firms that focus on low-cost and efficiency) do not see similar improvements in firm performance. Given that the benefits firms generate from IT depend on their chosen strategic orientation (Aral and Weill 2007; Tallon 2008), the impacts of IT orchestration capabilities that act upon the IT resource base could also vary between firms pursuing different strategic orientations.

We propose that the effect of IT application orchestration capability on agility depends on the firm's strategic orientation. Firms pursuing differentiation emphasize market responsiveness, flexibility, creativity, and innovation when building and managing the IT applications portfolio (Tallon 2007; Wang et al. 2012). Dynamic capabilities such as resource orchestration are directed towards flexibility and adaptation and, therefore, are central to achieving differentiation (Rindova and Kotha 2001; Sirmon et al. 2011; Teece et al. 1997). Firms pursuing operational excellence focus on IT-enabled process reliability, cost reduction, efficiency, and end-to-end supply 
chain optimization (Grant 2005; Tallon 2007; Treacy and Wiersema 1995). These firms do not require as much idiosyncratic applications and IT customization as firms pursuing differentiation. While both differentiation and operational excellence firms benefit from a strong IT application orchestration capability, studies suggest that orchestration capabilities become increasingly valuable as firms build idiosyncratic resources to enable differentiation strategies (Augier and Teece 2008; Rindova and Kotha 2001; Sirmon et al. 2011). Firms pursuing differentiation seek to enhance the value provided to customers beyond that which competitors provide (Augier and Teece 2008; Sirmon et al. 2011) and the IT application orchestration capability allows them to create unique combinations of IT resources in order to remain agile and ahead of competitors. Accordingly:

H2: The effect of IT application orchestration capability on agility is moderated by strategic orientation such that the effect is stronger in firms pursuing differentiation than in firms pursuing operational excellence.

\section{Mediating Role of Agility in Performance}

Firms realize greater performance gains from resources such as IT when they are able to produce new combinations of resources that are heterogeneous, valuable, inimitable, and imperfectly mobile across firm boundaries (Eisenhardt and Martin 2000; Helfat et al. 2007; Sirmon et al. 2011; Teece 2007; Teece et al. 1997). Previous IT capability studies provide support for this logic by showing that dynamic capabilities affect the amount of value firms derive from IT resources (Pavlou and El Sawy 2006, 2011; Roberts and Grover 2012). A strong IT application orchestration capability enables firms to continuously update their portfolio of IT applications and build novel combinations of IT resources to improve firm performance. For example, in 2009, Boeing introduced a new IT application - the Fleet Team Xchange to enable greater collaboration with airlines and to improve responsiveness to in-service issues. The new application integrates and extends the functionalities of two legacy collaboration applications (Jacintho and Jonge 2010). The company's continuous efforts to renew its IT applications portfolio also includes a new customer service portal that replaced less 
efficient methods of submitting service requests such as e-mail and fax (Numanoglu 2010) and a novel analytics tool to improve aircraft maintenance programs (McLoughlin et al. 2011).

In line with the discussion above, Sirmon et al. (2007) explain that firms renew or restructure their resource portfolios by purchasing resources, developing resources internally, and divesting existing resources. These are key competences that affect the ability of firms to generate performance gains from the resource base. For example, performance can be improved when firms acquire or develop resources that allow preferential access to future market opportunities (Sirmon et al. 2007; Tallon et al. 2016). This is often referred to as real options (McGrath and Nerkar 2004; Sirmon et al. 2007). In the case of IT resources that allow preferential access to future opportunities, this is usually referred to as digital options (Overby et al. 2006; Sambamurthy et al. 2003). By acquiring or developing IT applications as digital options, firms increase their repertoire of viable IT-based responses to market changes (Fichman 2004; Richardson et al. 2014; Tallon et al. 2016), which in turn enhances agility (Chakravarty et al. 2013; Overby et al. 2006). The holder of an option typically makes a small initial investment and holds it open until an opportunity arrives to leverage that investment (Sambamurthy et al. 2003). Divesting resources can also generate significant performance benefits. For example, as documented in HBS case studies on Cathay Pacific and General Dynamics (McFarlan and Seger 1993; McFarlan and Young 2003), the outsourcing process is a key mechanism through which firms retire resources that are not generating sufficient benefits. When a firm's objective is to get rid of legacy systems, this process usually involves the selection of IT applications to be retired (Earl 1996; Fisher et al. 2008; Kern and Willcocks 2001). Studies suggest that IT outsourcing can reduce IT costs, eliminate IT rigidities, improve support for business processes, and enhance time to market (Han and Mithas 2013; Lacity et al. 2010).

Accordingly, we postulate that IT application orchestration capability shapes and constrains the performance benefits firms generate from their IT applications portfolio. Since the first-order effects of IT materialize at the process level (Tallon et al. 2016), and in line with our discussion about agility above, we suggest that IT application orchestration capability affects firm performance through improved 
process agility. Specifically, IT application orchestration capability allows firms to continuously refresh the IT applications portfolio in order to reduce IT-based rigidities and speed up responses to market change, thus enabling agility. In addition, prior literature shows that agility is a key antecedent of firm performance (Chen et al. 2014; Roberts and Grover 2012; Tallon and Pinsonneault 2011). Drawing on the above literature and on studies that argue that IT capabilities impact performance through intermediate process-level outcomes (Barua et al. 2004; Chen et al. 2014; Mithas et al. 2011), we hypothesize the following:

H3: The effect of IT application orchestration capability on firm performance is mediated by agility.

\section{Research Method}

\section{Data Collection}

The data used to test our hypotheses were collected through an international survey of senior IT executives in 120 firms. The population of interest included a cross section of firms in the U.S., Australia, and Germany. ${ }^{4}$ From this population, we developed a sampling frame of 1,200 firms with 800 randomly selected from the U.S. and 400 from Australia and Germany. The survey was administered in 2012. In line with prior IT capability studies, we survey a key market-facing business unit within the organization rather than the organization as a whole (Roberts and Grover 2012). An organization may consider itself an operationally excellent firm in some markets but pursue differentiation in others. Hence, targeting key market-facing business units - also referred to as strategic business units (SBUs) - helps ensure meaningful assessments of strategic orientation (Venkatraman 1989). This is consistent with prior research that considers a market-facing business unit as a single-business firm competing in a particular product-market space (Lu and Ramamurthy 2011; Roberts and Grover 2012).

\footnotetext{
${ }^{4}$ U.S. firms were identified in S\&P Compustat. Data on Australian firms came from Australian Securities Exchange 200 (ASX 200) and a contact list maintained by researchers at the Center for Information Systems Research at the MIT Sloan School of Management. Data on German firms came from a contact list maintained by the Centre for Human Resources Information Systems at Bamburg University.
} 
We identified a Chief Information Officer (CIO) familiar with the market-facing business unit as our key informant. On average, respondents had been in their current role for eight years and had worked at the same firm for 12 years. Data were collected from firms based in the United States (42\%), Germany (40\%), and Australia (18\%). We also note a broad spectrum of industry groups in our sample: financial services (19\%), electronics (19\%), manufacturing (17\%), wholesale \& retail trade $(12 \%)$, energy (11\%), and other industries $(22 \%)$ comprising healthcare, engineering, and transportation.

Responses were received from 141 firms, yielding an initial response rate of $12 \%$. Twenty-one responses were excluded due to missing data and so our overall response rate is $10 \%$. While low, this is on par with response rates reported elsewhere in the IT capability literature and where respondents are senior IT executives (Karimi et al. 2007; Ravichandran and Lertwongsatien 2005; Roberts and Grover 2012). However, the potential for non-response bias needs to be investigated. Further, the use of a single respondent per firm raises the potential for common method bias. Our assessment of non-response bias and common method bias in Appendix B indicates that these biases are unlikely to be a major concern.

\section{Measures}

The survey questionnaire used to collect data for testing our research model is provided in Appendix C. We devised a measure for IT application orchestration capability and used validated measures from previous studies to assess process agility, strategic orientation, and firm performance. The survey design was refined using feedback from pilot tests with IT executive sponsors of member firms of the Center for Information Systems Research (CISR) at the MIT Sloan School of Management. Respondents were asked to rate each item on a five-point Likert type scale.

To measure process agility, we used a series of items taken from Tallon and Pinsonneault (2011). The eight reflective items we used map to the conceptualization of agility in Sambamurthy et al. (2003) where agility is seen in terms of customer, partnering, and operational agility. In addition, as shown in Appendix D, we also collected archival data on revenues, income, and profit for a three-year period to cross-validate this measure of agility. In order to measure strategic orientation, we used three items taken 
from Tallon (2008). This measure is based on Treacy and Wiersema's (1995) strategy typology that distinguishes between firms pursuing operational excellence and those pursuing differentiation through product innovation or customer intimacy. We asked respondents to allocate 100 points across the three categories of the Treacy and Wiersema (1995) typology: operational excellence, customer intimacy, and product leadership, with the greatest number of points going to the category that best fit the firm's selfidentified strategic orientation. This approach to measuring strategic orientation has been used in prior studies examining the organizational impacts of IT (Palmer and Markus 2000; Tallon 2007, 2008; Tallon et al. 2016; Weill and Broadbent 1998).

To devise our measure of IT application orchestration capability, we draw on prior literature that argues that firms renew their resource portfolios by (a) purchasing resources, (b) developing resources internally, and (c) divesting existing resources (Sirmon et al. 2007, 2011). Sirmon et al. (2007) explain that these competences are distinct and that each one of them is important for renewing a firm's resource base. Similarly, in the context of IT resources, prior literature argues that some firms are able to successfully negotiate and purchase valuable IT applications from suppliers (Tanriverdi 2006) but they do not necessarily possess the capabilities needed for developing IT applications internally (Lee and Xia 2010) or to quickly divest legacy IT applications (Van Oosterhout et al. 2006). Accordingly, our operationalization of IT application orchestration capability is based on formative items that combine to form the construct rather than reflective items that are used when each indicator is an "imperfect reflection of the construct" (MacKenzie et al. 2011, p. 295). In other words, the three competences above describe and form the IT application orchestration capability. The absence of any one competence would render the capability incomplete. Thus, we assess IT application orchestration capability using formative items that capture the ability of firms to build IT applications, purchase IT applications, and discontinue existing IT applications.

Past literature has measured firm performance using either archival measures such as return on assets and net profit or self-reported measures based on respondents' perceptions of performance relative 
to competitors. ${ }^{5}$ Given that our unit of analysis is the business unit, we note that while some archival performance data may be available for some firms, data that might typically be used to assess performance relative to competitors is rarely available in public archival sources (Tallon and Kraemer 2007; Wall et al. 2004). Accordingly, we decided to use a series of self-reported measures. This approach is consistent with prior IT capability research investigating relative measures of performance (Chen et al. 2014; Ravichandran and Lertwongsatien 2005). Following Powell and Dent-Micallef (1997), we devised a five-item scale containing questions about market share, revenues, sales growth, and profitability relative to competitors. Other studies that use this scale have reported its robustness (Kim et al. 2011). Moreover, as shown in Appendix D, we also collected archival performance data to cross-validate this measure of firm performance.

Finally, four control variables were used in our analysis to account for differences in industry type, pace of technology change within the industry, ownership structure (public/private), and firm size. Industry type was based on standard 2-digit SIC codes, while size was operationalized as the natural log of the number of employees.

\section{Data Analysis}

Data analysis was conducted using partial least squares (PLS), a structural equation modeling technique that uses a principal-component-based estimation approach (Chin 1998). Prior research suggests that PLS is an appropriate technique when analyzing predictive research models that include formatively modeled constructs (Fornell and Bookstein 1982; Hair et al. 2011; Ringle et al. 2012). ${ }^{6}$ To test our measurement model, we performed an exploratory analysis of the underlying questionnaire items.

\footnotetext{
${ }^{5}$ Collecting data using self-reported measures may be the only possible means either because: (1) archival data are not available (e.g., for private organizations that do not disclose financial records) or (2) archival data may be aggregated in a way that is not compatible with the level of interest. Research by Wall et al. (2004) that compared data collected using self-reported measures with archival data found evidence that self-reported measures are valid and reasonable for collecting business unit performance data. Tallon and Kraemer (2007) also found that selfreported perceptual measures of IT business value are valid substitutes if objective archival data are unavailable.

${ }^{6}$ The software package employed was SmartPLS 3.2.
} 
To evaluate our hypotheses, we estimate the research model shown earlier in Figure 1. Significance levels for each hypothesis were computed by applying the bootstrapping procedure with 1,000 samples.

Our research model contains potential moderation and mediation relationships. We used multigroup analysis to test our hypothesis that the effect of IT application orchestration capability is stronger in firms pursuing differentiation. To test the mediation effect of agility, we used the method proposed by Sobel (1982), commonly known as a Sobel test. This method has been widely used to test for mediation (Mithas et al. 2011; Tallon and Pinsonneault 2011). However, as the test is potentially biased due to an assumed normal sampling distribution (Zhao et al. 2010), Preacher and Hayes (2004) recommend a more rigorous bootstrap test that does not assume that the data are normally distributed. This paper applies both the Sobel and bootstrap approaches to test for mediation effects. For the bootstrap test, we used the PROCESS macro for SPSS given by Preacher and Hayes (2008).

\section{Research Results}

\section{Measurement Model Assessment}

The questionnaire items in Appendix $\mathrm{C}$ were analyzed to assess construct-to-item loadings, weights, validity, and reliability. We first reviewed construct-to-item loadings for our reflective constructs to identify whether item loadings were sufficient to warrant inclusion of an item under a specified construct. All item loadings exceeded a suggested minimum of 0.70 (Hair et al. 2011). In the case of formatively modeled constructs, one examines weights (instead of loadings), which represent a canonical correlation analysis and provide information about how each item contributes to the respective construct. We found that the three items of the IT application orchestration capability construct are significant and salient contributors to the construct index - the weights are $0.46,0.49$, and 0.46 respectively $(p<0.05$ in each instance).

In order to assess internal consistency, we next examined measures of composite reliability for each reflective construct (Raykov 1998). Reliability scores in excess of 0.70 are seen as acceptable in the early stages of research development, while a 
minimum standard of 0.80 is recommended for established constructs (Nunnally 1978; Werts et al. 1978). Table 1 below describes construct validity and reliability statistics and a correlation matrix for our constructs. Composite reliability measures for each construct comfortably exceed 0.80 .

To assess construct validity, we compared the square root of the average variance extracted (AVE) - the main diagonal in Table 1 - with off-diagonal elements that represent the correlation between each pair of constructs (Fornell and Larcker 1981). In Table 1, the square root of the AVE for each construct is greater than their associated off-diagonal correlations. Another standard validity concern is the potential for multicollinearity among constructs, which is known to produce unstable path estimates. To alleviate this concern, several collinearity tests were performed. Those tests revealed minimal collinearity among the constructs with all variance inflation factors (VIF) at or below 1.31 as against a suggested maximum of 10 for reflective constructs and a minimum of 3.3 for formative constructs (MacKenzie et al. 2011). Accordingly, we conclude that our construct measures are valid and reliable.

Table 1. Validity and Reliability Statistics and Correlations between Constructs

\begin{tabular}{|c|c|c|c|c|c|}
\hline Research Constructs & $\mathbf{C R}$ & AVE & 1 & 2 & 3 \\
\hline 1. Agility & 0.88 & 0.50 & 0.71 & & \\
\hline 2. IT Application Orchestration Capability & $\mathrm{N} / \mathrm{A}$ & N/A & 0.44 & N/A & \\
\hline 3. Performance & 0.91 & 0.66 & 0.43 & 0.23 & 0.81 \\
\hline \multicolumn{6}{|c|}{$\begin{array}{l}\text { Notes: } \mathrm{CR}=\text { Composite Reliability; AVE = Average Variance Extracted; N/A = not applicable due to the } \\
\text { formative nature of the IT Application Orchestration Capability construct; The bold numbers on the } \\
\text { diagonal are the square root of the AVE; Off-diagonal elements are correlations between each pair of } \\
\text { constructs. The binary measure of strategic orientation (differentiation / operational excellence) was used } \\
\text { to perform multigroup analysis. }\end{array}$} \\
\hline
\end{tabular}

\section{Hypothesis Testing}

We test our hypotheses by estimating the research model outlined in Figure 1. We first examine the relationships between IT application orchestration capability, agility, and firm performance and then investigate whether those relationships vary between firms pursuing differentiation and operational excellence. The results of our analysis appear in Table 2. 


\begin{tabular}{|c|c|c|c|c|}
\hline Relationships & $\begin{array}{l}\text { Full Sample } \\
(\mathrm{N}=120)\end{array}$ & $\begin{array}{l}\text { Firms Pursuing } \\
\text { Differentiation } \\
(\mathrm{N}=70)\end{array}$ & $\begin{array}{l}\text { Firms Pursuing } \\
\text { Operational } \\
\text { Excellence } \\
(\mathbf{N}=\mathbf{5 0})\end{array}$ & $\begin{array}{l}\text { Differentiation } \\
\text { vs Operational } \\
\text { Excellence } \Delta\end{array}$ \\
\hline $\begin{array}{l}\text { IT application orchestration } \\
\text { capability } \rightarrow \text { Agility }\end{array}$ & $0.44 * * *$ & $0.55 * * *$ & $0.35 * *$ & $0.20 *$ \\
\hline $\begin{array}{l}\text { IT application orchestration } \\
\text { capability } \rightarrow \text { Performance }\end{array}$ & $0.08^{\mathrm{N} / \mathrm{s}}$ & $-0.04^{\mathrm{N} / \mathrm{S}}$ & $0.18^{\mathrm{N} / \mathrm{S}}$ & $0.22 \mathrm{~N} / \mathrm{s}$ \\
\hline Agility $\rightarrow$ Performance & $0.41 * * *$ & $0.51 * * *$ & $0.31^{\dagger}$ & $0.20^{\mathrm{N} / \mathrm{s}}$ \\
\hline $\begin{array}{l}\text { Controls } \\
\text { Industry type } \\
\text { Size } \\
\text { Technology change in industry } \\
\text { Ownership structure }\end{array}$ & $\begin{array}{l}0.19^{\mathrm{N} / \mathrm{S}} \\
0.03^{\mathrm{N} / \mathrm{s}} \\
-0.08^{\mathrm{N} / \mathrm{s}} \\
-0.06^{\mathrm{N} / \mathrm{s}}\end{array}$ & $\begin{array}{l}-0.23^{\mathrm{N} / \mathrm{S}} \\
-0.01^{\mathrm{N} / \mathrm{s}} \\
-0.19^{\mathrm{N} / \mathrm{s}} \\
0.01^{\mathrm{N} / \mathrm{S}}\end{array}$ & $\begin{array}{l}0.03^{\mathrm{N} / \mathrm{S}} \\
0.17^{\mathrm{N} / \mathrm{S}} \\
0.02^{\mathrm{N} / \mathrm{S}} \\
-0.07^{\mathrm{N} / \mathrm{s}}\end{array}$ & $\begin{array}{l}0.26^{\mathrm{N} / \mathrm{s}} \\
0.18^{\mathrm{N} / \mathrm{s}} \\
0.21^{\mathrm{N} / \mathrm{S}} \\
0.08^{\mathrm{N} / \mathrm{s}}\end{array}$ \\
\hline $\begin{array}{l}\text { Variance Explained }\left(R^{2}\right) \\
\text { Performance } \\
\text { Agility }\end{array}$ & $\begin{array}{l}23 \% \\
19.4 \%\end{array}$ & $\begin{array}{l}30.2 \% \\
29.7 \%\end{array}$ & $\begin{array}{l}32 \% \\
12.7 \%\end{array}$ & $\begin{array}{l}0.02^{\mathrm{N} / \mathrm{S}} \\
0.17^{*}\end{array}$ \\
\hline
\end{tabular}

$* * * p<0.001 ; * * p<0.01 ; * p<0.05 ; \dagger p<0.1 ; \mathrm{N} / \mathrm{S}$ : not significant.

All tests are two-tailed, except for $\Delta \mathrm{R}^{2}$ sig. in multigroup comparison where the coefficients have the predicted signs. Our sample includes firms based in different countries. A multigroup analysis comparing the relationships in our model across countries found no significant differences.

The results in Table 2 for $\mathrm{H} 1$ find a positive and significant effect of IT application orchestration capability on agility $(\beta=0.44 ; p<0.001)$. Hence, $\mathrm{H} 1$ is supported. The results for $\mathrm{H} 2$ show that the relationship between IT application orchestration capability and agility is stronger for firms pursuing differentiation $\left(\Delta \mathrm{R}^{2}=0.17, p<0.05\right)$. Therefore, $\mathrm{H} 2$ is supported. Lastly, $\mathrm{H} 3$ denotes the indirect effect of IT application orchestration capability on performance. Thus, we test for mediation. The Sobel and bootstrap tests for mediation reveal that IT application orchestration capability has a significant indirect effect on performance through agility (indirect effect $=0.18$; Sobel: $z=3.34, p<0.001$; bootstrap 95\% C.I. 0.07 to 0.31 ). Therefore, $\mathrm{H} 3$ is supported. The results for the control variables find that the effects of industry type, size, ownership structure, and industry-level pace of technology change were not significant. 


\section{Additional Analysis}

In their study of the performance impacts of IT capabilities, Chae et al. (2014) found no significant direct link between IT capabilities and performance. They argue that further research is needed to extend our knowledge of the conditions under which IT capabilities affect performance. Accordingly, we performed additional analysis to further delineate the relationship between IT application orchestration capability and firm performance.

The way a firm utilizes IT depends not only on the business strategy adopted but also on whether its focus is on exploitation or exploration (Burton-Jones and Straub 2006; Subramani 2004). Exploitation focuses on the routine application of existing knowledge for achieving efficiency and is central to operational excellence strategies. Exploration focuses on the search for novel or innovative ways of performing business activities, something which is central to differentiation strategies (Thornhill and White 2007). Firms that are able to pursue exploitation and exploration activities simultaneously, i.e. ambidextrous firms, can achieve both efficiency and flexibility (Gibson and Birkinshaw 2004; He and Wong 2004; O’Reilly and Tushman 2008, 2011; Raisch and Birkinshaw 2008). Hence, a firm's decision to focus on exploration or exploitation may affect its ability to execute its chosen business strategy (Atuahene-Gima 2005; Thornhill and White 2007). When it comes to market positioning, firms can improve firm performance by combining elements of operational excellence and differentiation strategies (Raisch and Birkinshaw 2008). However, this approach is not a panacea since firms risk becoming stuck in the middle with no clear strategy (Cennamo and Santalo 2015; Porter 1985; Thornhill and White 2007). Hence, a growing body of literature seeks to understand the conditions under which mixed-focus strategies are preferable to a singular focus on either operational excellence or differentiation (Parnell 2000; Raisch and Birkinshaw 2008; Shinkle et al. 2013; Spanos et al. 2004; Tallon 2007; Thornhill and White 2007).

In line with this stream of research, we examine how the performance effects of IT application orchestration capability vary when firms shift their strategic focus from singular to mixed-focus 
strategies. To do this, we used Hayes's (2013) regression-based approach for testing conditional effects. This approach allows us to examine how the effects of IT application orchestration capability change as a function of strategic orientation. It also allows us to create percentile-based confidence intervals for the effects of IT application orchestration capability at various levels of strategic orientation. We estimated two models using the PROCESS macro for SPSS with 1,000 bootstrap samples (Hayes 2013; Preacher and Hayes 2008). The first model tests the effects of IT application orchestration capability on firm performance when agility is not included in the analysis. The second model tests the effects of IT application orchestration capability when controlling for the effects of agility. Strategic orientation ranges from a focus on operational excellence $\left(10^{\text {th }}\right.$ and $25^{\text {th }}$ percentiles of the strategic orientation values) to mixed-focus strategies $\left(50^{\text {th }}\right.$ percentile) and differentiation $\left(75^{\text {th }}\right.$ and $90^{\text {th }}$ percentiles $)$. The results of our analysis are shown in Figures $2 \mathrm{a}$ and $2 \mathrm{~b}$.

The results in Figure 2a show that IT application orchestration capability has significant positive effects on the performance of firms pursing mixed-focus strategies $(\beta=0.23 ; p<0.05)$ and those leaning toward operational excellence $(\beta=0.26 ; p<0.05)$ but only when agility is omitted from the analysis. When we account for the effect of agility, the effects of IT application orchestration capability are not significant as shown in Figure $2 \mathrm{~b}$. This demonstrates the importance of identifying and accounting for mediators and other variables that potentially affect the relationship between IT capabilities and performance (Chae et al. 2014). The results of additional analysis in Figure 2 are consistent with our discussion above about the mediating effects of agility on firm performance.

Figure 2. Conditional Effects of IT Application Orchestration Capability on Firm Performance (a) Agility excluded from analysis 


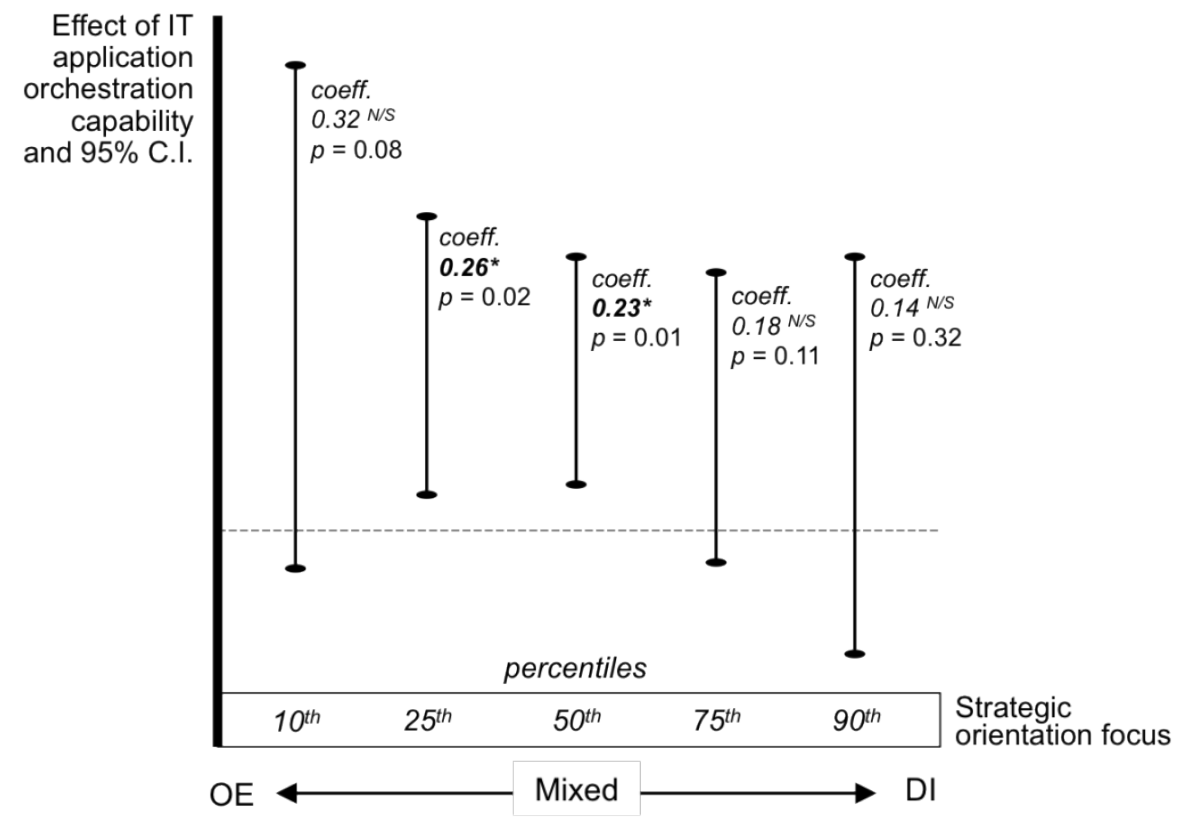

(b) Controlling for the effects of agility

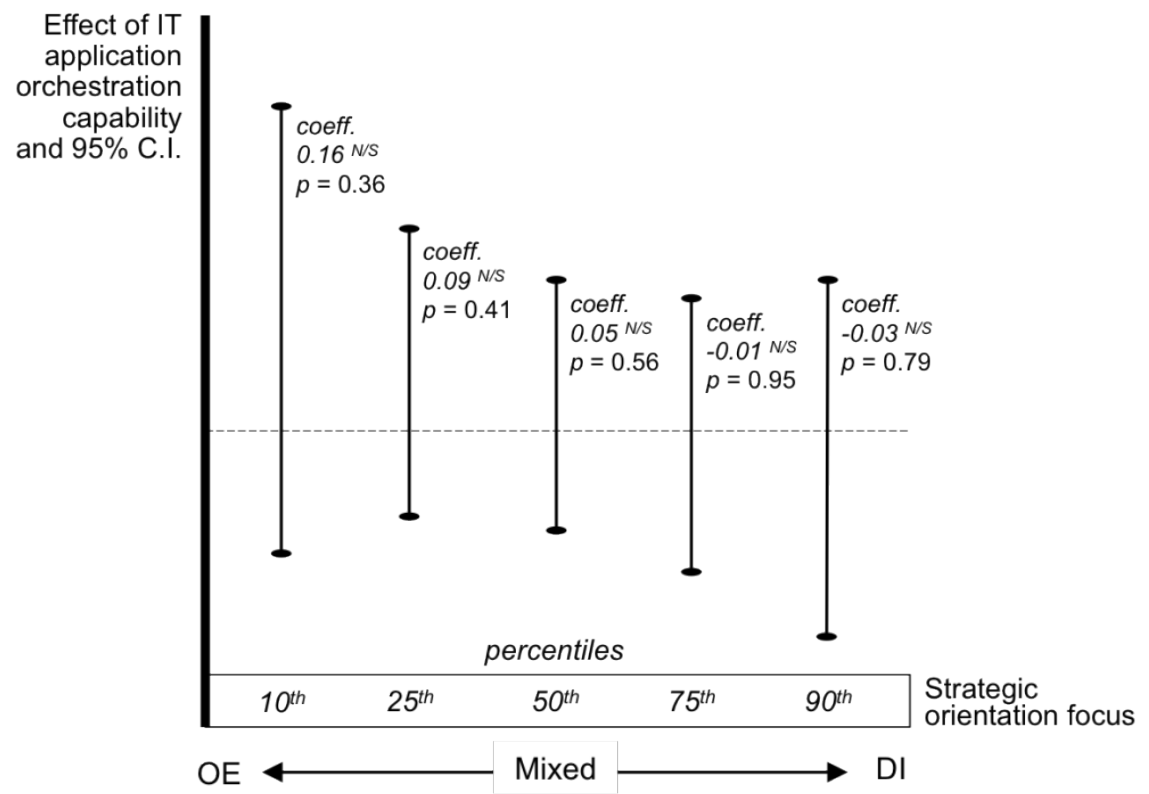

Notes: * Significant at the 0.05 level; N/S: not significant; dotted line = zero point for confidence interval (C.I.); OE $=$ operational excellence; $\mathrm{DI}=$ differentiation.

\section{Discussion}

With increasing competitive rivalry and shifting customer demands, there is a greater interest in understanding how firms build and maintain a portfolio of IT applications to stay ahead of competitors 
(Nazir and Pinsonneault 2012). In practice, most firms are eager to add new applications to their IT portfolios but they are not as keen to retire legacy IT applications (Gomolski 2004). Thus, IT application portfolios can grow quickly and become difficult to manage. We began this paper by arguing that firms can achieve significant performance benefits when they renew their IT application portfolios. By conceptualizing IT application orchestration capability and testing a theory about its performance impacts, we show how firms realize these benefits. Our study finds that IT application orchestration capability has a positive effect on both agility and firm performance. Further, it finds that organizations' strategic orientation moderates the relationship between IT application orchestration capability and agility. Specifically, firms pursuing differentiation obtain a greater effect on agility from increased IT application orchestration as compared to firms pursuing operational excellence.

\section{Contribution of the Research}

This study makes important contributions to research. First, it introduces the concept of IT application orchestration capability and theorizes about how it creates value for firms. We conceive of this as a dynamic capability that can influence firm performance. This conceptualization extends prior research on the performance implications of IT capabilities. For instance, Mithas et al. (2011) investigate the effects of information management capability on performance while Roberts and Grover (2012), Lu and Ramamurthy (2011), and Fink and Neumann (2007) investigate the effects of IT infrastructure capabilities. While past research has focused on IT infrastructure, IT application orchestration concerns the capacity of firms to manage their evolving IT application portfolios. This is an important research question in modern times where firms can easily outsource IT infrastructure or procure infrastructure as a service (Kappelman et al. 2014). Within that context, it is important to investigate the distinct effects of capabilities related to IT applications and how those capabilities impact firm performance.

Second, our study extends prior literature investigating the relationship between IT capabilities and firm performance. Prior research on this topic evolved in a context where IT infrastructure was inhouse and firms had to undertake major capital investment on long-term projects to build the IT 
infrastructure. Within that context, a focus on IT infrastructure-related capabilities was justified. Nevertheless, even in that context, there was a broad realization that performance gains accrued mostly from IT applications such as customer relationship management, data management, and intra-firm collaboration systems that sat on top of the infrastructure. For example, Weill and Broadbent (1998) and Weill and Vitale (2002) describe a firm's IT architecture as a triangle with IT infrastructure in the bottom layer supporting IT applications at the top. Similarly, Weill et al. (2002) describe a set of capabilities, including data management, intra-firm communications, and channel management that high-performing firms should have. Those capabilities implicitly assume a world described in Weill and Vitale (2002) where IT infrastructure and applications development are intertwined. This study extends that line of research by arguing that the assumption of a tight coupling between infrastructure and applications that underpinned prior research needs to be relaxed. We relax that assumption and propose a conceptual model where IT applications-related capabilities exert distinct effects on firm performance independent of IT infrastructure-related capabilities.

Third, this study also extends our understanding of the effect of agility on firm performance by proposing IT application orchestration capability as an antecedent of agility as well as an enabler of firm performance. Prior research, while arguing for the important role of IT on agility and the effect of agility on firm performance (Overby et al. 2006; Sambamurthy et al. 2003; Tallon and Pinsonneault 2011), has not identified IT applications-related capabilities as antecedents of agility. This study extends that stream of research by identifying IT application orchestration capability as an antecedent of agility and by identifying agility as a key mechanism through which IT application orchestration capability improves firm performance.

Fourth, this study highlights the role of strategic orientation in the effects of IT application orchestration capability. It shows that strategic orientation moderates the effect of IT application orchestration capability on agility such that the effect is stronger in firms pursuing differentiation rather than operational excellence. This finding helps demonstrate how strategic orientation affects the ability of 
firms to generate benefits such as increased agility and performance. It is in line with existing literature that argues that a firm's choice of strategic orientation has a considerable impact on its performance as well as on its ability to compete in increasingly turbulent and uncertain market environments (Drnevich and Croson 2013; Raisch and Birkinshaw 2008).

\section{Implications for Research and Practice}

A noted determinant of a firm's success is its ability to effectively manage strategic contradictions and trade-offs (Adler et al. 1999; Smith and Lewis 2011; Smith and Tushman 2005). Research into ambidexterity argues that firms who engage in exploration and exploitation simultaneously are more likely to achieve superior performance outcomes (Andriopoulos and Lewis 2009; Gibson and Birkinshaw 2004; He and Wong 2004; O’Reilly and Tushman 2008; Patel et al. 2013; Raisch and Birkinshaw 2008; Tushman and O'Reilly 1996). For example, He and Wong (2004) find that the interaction between explorative and exploitative innovation strategies is related to an increase in sales growth. Similarly, marketing scholars examine how firms can solve strategic dilemma in product innovation (Atuahene-Gima 2005) and discuss the benefits that accrue when firms pursue cross-functional cooperation and competition simultaneously (Luo et al. 2006). Furthermore, strategy scholars have long been investigating whether firms pursuing mixed-focus strategies outperform those with a singular focus (Ghemawat and Costa 1993; Parnell 2000; Shinkle et al. 2013; Spanos et al. 2004; Thornhill and White 2007). Porter (1985) argues that firms who combine different business strategies can get stuck in the middle with no clear strategy. In line with this premise, Thornhill and White (2007) find that firms with a singular focus on either operational excellence or product leadership perform as well as or better than those with mixed-focus strategies. Ebben and Johnson (2005) report similar results. However, Thornhill and White (2007) note that "although difficult, a balance between strategies may be successfully struck at least by some organizations in some situations, some of the time" (p. 555).

When it comes to the relationship between IT application orchestration capability and performance, our study finds no significant differences between firms pursuing mixed-focus strategies 
and those with a singular focus. IT application orchestration capability will benefit firms pursuing mixedfocus strategies as well as those with a singular focus, albeit in different ways. For firms pursuing operational excellence, it enables them to build an IT portfolio based mostly on general purpose IT and standardized IT applications that can be purchased from vendors and rapidly discontinued if needed. This can increase efficiency and lower IT maintenance costs. For firms pursuing differentiation, IT application orchestration capability allows them to focus on the development of idiosyncratic IT applications to support innovation and time-to-market. It also allows them to quickly divest legacy systems that could slow down new IT deployments. This makes it difficult for competitors to imitate the IT portfolio since it is a moving target comprised mostly of applications that are continuously updated. For firms pursuing mixed-focus strategies, IT application orchestration capability helps them build a balanced portfolio comprised of both standardized IT applications, whose purpose is to increase efficiency, and idiosyncratic IT applications to support innovation. As these firms seek to adapt to market discontinuities, IT application orchestration capability allows them to more easily shift the balance of their IT application portfolios, for instance, by focusing on new applications aimed at boosting efficiency or increasing the emphasis on IT-enabled innovation. In short, IT application orchestration is an important capability that enables the firm to alter its portfolio of IT applications to address market changes.

On the other hand, a number of recent developments, such as cloud sourcing and processsourcing suggest that capabilities related to IT infrastructure are getting commoditized and that firms are increasingly able to access those through the market (Carr 2003). Firms are now able to quickly scale up and down their IT infrastructure with relatively little cost penalties. Many firms now see IT infrastructure as operational expenditure (opex) rather than as capital expenditure (capex). The implications of not optimizing on IT infrastructure are not as severe and, more importantly, are easily reversible. Under those circumstances, capabilities related to IT infrastructure are no longer as critical as they once were. What is critical for firms in the emerging context is their ability to build and manage a growing portfolio of IT 
applications to capitalize on new market opportunities. This has important implications for IT and business executives.

Foremost, executives will need to revisit the assumptions underpinning their IT governance structures and the structural arrangements in place for ensuring alignment between IT and business strategy. With IT infrastructure decisions taken out of the equation, there is a possibility for closer coupling between IT resources and business activities (Richard et al. 2012; Tallon et al. 2016). In particular, in multi-business firms the interdependencies between business units on account of shared IT infrastructure get finessed. For example, business units can work directly with corporate IT managers on IT investments and the development of IT applications without impinging on other business units' ability to leverage the shared IT infrastructure. Further, since IT applications projects are much smaller and shorter than infrastructure projects, the risks involved in investing in IT applications are usually much lower. This could potentially push IT investment decisions further down in the organizational hierarchy and add to the agility of the firm. However, this presupposes that firms will be able to unwind their existing governance structures, which were developed primarily for a world where there were significant interdependencies between business units on account of shared IT infrastructure and enterprise systems, where planning horizons were longer, and where the risks of failure were higher.

Further, strategic considerations would need to become more central to decisions relating to IT applications. The findings of this study suggest that firms pursuing differentiation strategies will need to invest in developing high levels of IT application orchestration capability in order to increase market responsiveness. This could be achieved by altering governance processes, in particular streamlining processes for identifying and resourcing IT applications that generate strategic benefits. In addition, firms will need to develop and implement change management processes for quickly identifying and divesting IT applications that are no longer generating value. These applications likely consume valuable IT capital and the attention of IT personnel who could be better employed identifying and developing strategic IT applications for future business use. 


\section{Future Research Possibilities}

Our findings suggest several questions that could be explored in future work. One such question is whether the characteristics of the resource allocation process, such as formalization and centralization as embodied within IT governance processes, structures, and relationships, influence IT application orchestration capability. This question could build on the work of Anand et al. (2016) who explain the key role of organizational resource allocation processes in leveraging the impact of IT investments and capabilities into performance. Future research could also investigate how IT application orchestration capability and the characteristics of the resource allocation process jointly influence agility and firm performance.

Firms that have honed their IT application orchestration capabilities can more easily acquire, build, and retire IT applications. An important challenge for those firms is how to best manage the growing IT applications portfolio to minimize IT disruptions when implementing changes and to ensure that the IT portfolio supports the firm's strategic objectives. Future studies could investigate how IT application orchestration capability relates to the ability to achieve and maintain alignment between IT and business strategy (Coltman et al. 2015; Queiroz 2017). It would also be useful for future research to investigate key antecedents of IT application orchestration capability. Such research could provide valuable insights into the relationship between IT application orchestration capability and organizational actions and processes such as governance processes, outsourcing, vendor relationship management, and change management.

Another important question for future research is the role of environmental factors in explaining the effects of IT application orchestration capability. Previous studies suggest that market turbulence and uncertainty can affect the relationship between IT capabilities and performance (Chakravarty et al. 2013; Chen et al. 2014). Future studies could investigate whether and how environmental factors influence the effects of IT application orchestration capability. Firms pursuing differentiation strategies and those seeking to be ambidextrous usually compete in more turbulent environments (Slater and Narver 1994; 
Tsai and Yang 2013). Therefore, examining the effects of environmental factors on IT application orchestration capability could be particularly important for those firms.

\section{Limitations}

Despite the strength of our findings and the opportunities for future research, there are also a number of limitations to this study. First, our research uses cross-sectional data and so we are limited in our ability to discern cause-and-effect relationships. To mitigate that concern we collected archival data on performance for a three-year period and used that data to validate the self-reported measure of firm performance. In addition, we used that data to assess the measure of agility against performance growth rate measures. The analysis in Appendix D shows that the self-reported measure of performance correlates with archival performance data and that the self-reported measure of agility correlates with current and future growth rate measures. Future growth rate includes a one-year lag in sales revenue, profit, and income data. While the analysis reported in Appendix D mitigates this limitation to a certain extent, it also suggests that future research should seek to test and extend our research model using longitudinal data.

Second, a validity threat to the findings of this study arises from common method bias (CMB). Estimating the extent of CMB within a single study is challenging because assessments of method effects usually account for variability in methods across multiple studies (Chin et al. 2012; Sharma et al. 2009). Recognizing this, prior literature draws attention to important factors, including data characteristics and the pattern of relationships among variables in the research model, which should be taken into consideration when assessing CMB within a single study. For example, method effects are less likely to generate spurious moderation effects because it is unlikely that respondents would be able to anticipate the complex patterns of relationships among variables to produce an interaction effect (Tsai and Bagozzi 2014). The results of our study show that strategic orientation moderates the effect of IT application orchestration capability. In addition, prior literature provides recommendations for mitigating concerns with $\mathrm{CMB}$, including guidelines for survey instrument development, assessment of construct correlations, 
and the use of archival data to conduct validity checks. We followed those recommendations as shown in Appendix B.

Third, it is important to note that our focus in this study is at the business unit level within a broader firm context. As such, we do not delve into the all-important question of how IT application orchestration capability transmits its effects to agility. The mechanics of how this happens is a critical area for further study. We envision, for example, the need to look within individual processes and across processes to see how decisions to build, buy or retire IT applications relate to agility within a process or, more broadly, within a value chain, shop or network (Stabell and Fjeldstad 1998). Our measures of IT application orchestration capability could be refined and broadened to help underscore the need to assess issues involving application ownership, governance, and control. Similarly, despite its popularity, process agility is not the only conceptualization of agility in the literature and so we envision different opportunities to consider finer slices of the relationship between IT orchestration capabilities and agility.

\section{Conclusion}

Our study examines the performance consequences of a firm's ability to renew its portfolio of IT applications. It shows that IT application orchestration capability is central to building and improving a firm's IT portfolio to ensure that IT applications are current with its business needs. When firms build IT application orchestration capability, they create value by improving their IT resource base, thus enhancing process agility and increasing firm performance. We propose that this capability is particularly relevant to firms pursuing differentiation since those firms depend on innovation and market responsiveness to stay ahead of competitors. The results of our study show that IT application orchestration capability affects process agility and that those effects are stronger in firms pursuing differentiation. The results also show that this capability improves performance though agility. We hope our study will stimulate investigations of IT applications-related capabilities, such as capabilities for building and managing IT application portfolios, and encourage further debate on the effects those capabilities exert on performance. 


\section{References}

Adler, P., Goldoftas, B., and Levine, D. 1999. "Flexibility Versus Efficiency? A Case Study of Model Changeovers in the Toyota Production System," Organization Science (10:1), pp. 43-68.

Ambrosini, V., Bowman, C., and Collier, N. 2009. "Dynamic Capabilities: An Exploration of How Firms Renew Their Resource Base," British Journal of Management (20:1), pp. S9-S24.

Anand, A., Sharma, R., and Coltman, T. 2016. "Four Steps to Realizing Business Value from Digital Data Streams," MIS Quarterly Executive (15:1), pp. 20-30.

Andriopoulos, C., and Lewis, M.W. 2009. "Exploitation-Exploration Tensions and Organizational Ambidexterity: Managing Paradoxes of Innovation," Organization Science (20:4), pp. 696-717.

Aral, S., and Weill, P. 2007. "IT Assets, Organizational Capabilities, and Firm Performance: How Resource Allocations and Organizational Differences Explain Performance Variation," Organization Science (18:5), pp. 763-780.

Atuahene-Gima, K. 2005. "Resolving the Capability—Rigidity Paradox in New Product Innovation," Journal of Marketing (69:4), pp. 61-83.

Augier, M., and Teece, D.J. 2008. "Strategy as Evolution with Design: The Foundations of Dynamic Capabilities and the Role of Managers in the Economic System," Organization Studies (29:8-9), pp. 1187-1208.

Barua, A., Konana, P., Whinston, A., and Yin, F. 2004. "An Empirical Investigation of Net-Enabled Business Value," MIS Quarterly (28:4), pp. 585-620.

Barua, A., Kriebel, C.H., and Mukhopadhyay, T. 1995. "Information Technologies and Business Value: An Analytic and Empirical Investigation," Information Systems Research (6:1), pp. 3-23.

Bharadwaj, A.S. 2000. "A Resource-Based Perspective on Information Technology Capability and Firm Performance: An Empirical Investigation," MIS Quarterly (24:1), pp. 169-196.

Bhatt, G.D., and Grover, V. 2005. "Types of Information Technology Capabilities and Their Role in Competitive Advantage: An Empirical Study," Journal of Management Information Systems (22:2), pp. 253-277.

Boh, W.F., and Yellin, D. 2007. "Using Enterprise Architecture Standards in Managing Information Technology," Journal of Management Information Systems (23:3), pp. 163-207.

Broadbent, M., Weill, P., and St. Clair, D. 1999. "The Implications of Information Technology Infrastructure for Business Process Redesign," MIS Quarterly (23:2), pp. 159-182.

Burton-Jones, A., and Straub, D.W. 2006. "Reconceptualizing System Usage: An Approach and Empirical Test," Information Systems Research (17:3), pp. 228-246.

Carr, N.G. 2003. "IT Doesn't Matter," Harvard Business Review (81:5), pp. 41-49.

Cennamo, C., and Santalo, J. 2015. "How to Avoid Platform Traps," MIT Sloan Management Review (57:1), p. 12.

Chae, H.-C., Koh, C.E., and Prybutok, V.R. 2014. "Information Technology Capability and Firm Performance: Contradictory Findings and Their Possible Causes," MIS Quarterly (38:1), pp. 305-326.

Chakravarty, A., Grewal, R., and Sambamurthy, V. 2013. "Information Technology Competencies, Organizational Agility, and Firm Performance: Enabling and Facilitating Roles," Information Systems Research (24:4), pp. 976-997.

Chen, H., Chiang, R.H., and Storey, V.C. 2012. "Business Intelligence and Analytics: From Big Data to Big Impact," MIS Quarterly (36:4), pp. 1165-1188.

Chen, Y., Wang, Y., Nevo, S., Jin, J., Wang, L., and Chow, W.S. 2014. "IT Capability and Organizational Performance: The Roles of Business Process Agility and Environmental Factors," European Journal of Information Systems (23:3), pp. 326-342.

Chin, W.W. 1998. "The Partial Least Squares Approach for Structural Equation Modeling," in Modern Methods for Business Research, G.A. Marcoulides (ed.). London: Lawrence Erlbaum Associates, pp. 295 - 336. 
Chin, W.W., Thatcher, J.B., and Wright, R.T. 2012. "Assessing Common Method Bias: Problems with the ULMC Technique," MIS Quarterly (36:3), pp. 1003-1019.

Clark, C.E., Cavanaugh, N.C., Brown, C.V., and Sambamurthy, V. 1997. "Building Change-Readiness Capabilities in the IS Organization: Insights from the Bell Atlantic Experience," MIS Quarterly (21:4), pp. 425-455.

Coltman, T. 2007. "Why Build a Customer Relationship Management Capability?," The Journal of Strategic Information Systems (16:3), pp. 301-320.

Coltman, T., Tallon, P.P., Sharma, R., and Queiroz, M. 2015. "Strategic IT Alignment: Twenty-Five Years On," Journal of Information Technology (30:2), pp. 91-100.

Drnevich, P.L., and Croson, D.C. 2013. "Information Technology and Business-Level Strategy: Toward an Integrated Theoretical Perspective," MIS Quarterly (37:2), pp. 483-509.

Earl, M.J. 1996. "The Risks of Outsourcing IT," Sloan Management Review (37:3), pp. 26-32.

Ebben, J.J., and Johnson, A.C. 2005. "Efficiency, Flexibility, or Both? Evidence Linking Strategy to Performance in Small Firms," Strategic Management Journal (26:13), pp. 1249-1259.

Eggers, J., and Kaplan, S. 2013. "Cognition and Capabilities: A Multi-Level Perspective," The Academy of Management Annals (7:1), pp. 295-340.

Eisenhardt, K.M., and Martin, J.A. 2000. "Dynamic Capabilities: What Are They?," Strategic Management Journal (21:10), pp. 1105-1121.

Fichman, R.G. 2004. "Real Options and IT Platform Adoption: Implications for Theory and Practice," Information Systems Research (15:2), pp. 132-154.

Fink, L., and Neumann, S. 2007. "Gaining Agility through IT Personnel Capabilities: The Mediating Role of IT Infrastructure Capabilities," Journal of the Association for Information Systems (8:8), pp. 440462.

Fisher, J., Hirschheim, R., and Jacobs, R. 2008. "Understanding the Outsourcing Learning Curve: A Longitudinal Analysis of a Large Australian Company," Information Systems Frontiers (10:2), pp. 165-178.

Fornell, C., and Bookstein, F.L. 1982. "Two Structural Equation Models: LISREL and PLS Applied to Consumer Exit-Voice Theory," Journal of Marketing Research (19:4), pp. 440-452.

Fornell, C., and Larcker, D.F. 1981. "Structural Equation Models with Unobservable Variables and Measurement Error: Algebra and Statistics," Journal of Marketing Research (18:1), pp. 382-388.

Germann, F., Lilien, G.L., and Rangaswamy, A. 2013. "Performance Implications of Deploying Marketing Analytics," International Journal of Research in Marketing (30:2), pp. 114-128.

Ghemawat, P., and Costa, J. 1993. "The Organizational Tension between Static and Dynamic Efficiency," Strategic Management Journal (14:S2), pp. 59-73.

Gibson, C.B., and Birkinshaw, J. 2004. "The Antecedents, Consequences, and Mediating Role of Organizational Ambidexterity," Academy of Management Journal (47:2), pp. 209-226.

Gomolski, B. 2004. "Cleaning House." Computerworld. https://www.computerworld.com.au/article/3894/cleaning house/ (accessed 16 October 2017).

Goodhue, D.L., Wixom, B.H., and Watson, H.J. 2002. "Realizing Business Benefits through CRM: Hitting the Right Target in the Right Way," MIS Quarterly Executive (1:2), pp. 79-94.

Grant, R.M. 2005. Contemporary Strategy Analysis, (5th ed.). Malden: Blackwell Pub.

Hair, J.F., Ringle, C.M., and Sarstedt, M. 2011. "PLS-SEM: Indeed a Silver Bullet," The Journal of Marketing Theory and Practice (19:2), pp. 139-152.

Han, K., and Mithas, S. 2013. "Information Technology Outsourcing and Non-IT Operating Costs: An Empirical Investigation," MIS Quarterly (37:1), pp. 315-331.

Hayes, A.F. 2013. Introduction to Mediation, Moderation, and Conditional Process Analysis: A Regression-Based Approach. New York, NY: Guilford Press.

He, Z.-L., and Wong, P.-K. 2004. "Exploration Vs. Exploitation: An Empirical Test of the Ambidexterity Hypothesis," Organization Science (15:4), pp. 481-494. 
Helfat, C.E., Finkelstein, S., Mitchell, W., Peteraf, M.A., Singh, H., and Teece, D.J. 2007. Dynamic Capabilities: Understanding Strategic Change in Organizations. New York: Wiley-Blackwell Publishing.

Jacintho, S., and Jonge, K. 2010. "New Tool for Collaboration on in-Service Issues," Boeing AeroMagazine (38:2), pp. 20-23.

Kappelman, L., McLean, E., Johnson, V., and Gerhart, N. 2014. "The 2014 SIM IT Key Issues and Trends Study," MIS Quarterly Executive (13:4), pp. 237-263.

Kappelman, L., McLean, E., Johnson, V., and Torres, R. 2016. "The 2015 SIM IT Issues and Trends Study," MIS Quarterly Executive (15:1), pp. 55-83.

Karimi, J., Somers, T.M., and Bhattacherjee, A. 2007. "The Role of Information Systems Resources in ERP Capability Building and Business Process Outcomes," Journal of Management Information Systems (24:2), pp. 221-260.

Kern, T., and Willcocks, L. 2001. The Relationship Advantage: Information Technologies, Sourcing, and Management. Oxford University Press.

Kim, G., Shin, B., Kim, K.K., and Lee, H.G. 2011. "IT Capabilities, Process-Oriented Dynamic Capabilities, and Firm Financial Performance," Journal of the Association for Information Systems (12:7), pp. 487-517.

Koch, H. 2010. "Developing Dynamic Capabilities in Electronic Marketplaces: A Cross-Case Study," The Journal of Strategic Information Systems (19:1), pp. 28-38.

Lacity, M.C., Khan, S., Yan, A., and Willcocks, L.P. 2010. "A Review of the IT Outsourcing Empirical Literature and Future Research Directions," Journal of Information Technology (25:4), pp. 395-433.

Lee, G., and Xia, W. 2010. "Toward Agile: An Integrated Analysis of Quantitative and Qualitative Field Data on Software Development Agility," MIS Quarterly (34:1), pp. 87-114.

Lee, O.-K., Sambamurthy, V., Lim, K.H., and Wei, K.K. 2015. "How Does IT Ambidexterity Impact Organizational Agility?," Information Systems Research (26:2), pp. 398-417.

Leiblein, M.J., Reuer, J.J., and Dalsace, F. 2002. "Do Make or Buy Decisions Matter? The Influence of Organizational Governance on Technological Performance," Strategic Management Journal (23:9), pp. 817-833.

Leonard-Barton, D. 1992. "Core Capabilities and Core Rigidities: A Paradox in Managing New Product Development," Strategic Management Journal (13:1), pp. 111-125.

Lu, Y., and Ramamurthy, K. 2011. "Understanding the Link between Information Technology Capability and Organizational Agility: An Empirical Examination," MIS Quarterly (35:4), pp. 931-954.

Luftman, J., Zadeh, H.S., Derksen, B., Santana, M., Rigoni, E.H., and Huang, Z.D. 2012. "Key Information Technology and Management Issues 2011-2012: An International Study," Journal of Information Technology (27:3), pp. 198-212.

Luftman, J., Zadeh, H.S., Derksen, B., Santana, M., Rigoni, E.H., and Huang, Z.D. 2013. "Key Information Technology and Management Issues 2012-2013: An International Study," Journal of Information Technology (28:4), pp. 354-366.

Luo, X., Slotegraaf, R.J., and Pan, X. 2006. "Cross-Functional "Coopetition": The Simultaneous Role of Cooperation and Competition within Firms," Journal of Marketing (70:2), pp. 67-80.

MacKenzie, S.B., Podsakoff, P.M., and Podsakoff, N.P. 2011. "Construct Measurement and Validation Procedures in MIS and Behavioral Research: Integrating New and Existing Techniques," MIS Quarterly (35:2), pp. 293-334.

McAfee, A. 2003. "When Too Much IT Knowledge Is a Dangerous Thing," MIT Sloan Management Review (44:2), pp. 83-89.

McFarlan, F.W., and Seger, K. 1993. "General Dynamics and Computer Sciences Corporation: Outsourcing the IS Function." Harvard Business School Case no. 193178.

McFarlan, F.W., and Young, F. 2003. "Cathay Pacific: Doing More with Less." Harvard Business School Case no. 303106. 
McGrath, R., and Nerkar, A. 2004. "Real Options Reasoning and a New Look at the R\&D Investment Strategies of Pharmaceutical Firms," Strategic Management Journal (25:1), pp. 1-21.

McLoughlin, B., Doulatshahi, F., and Onorati, J. 2011. "Improving Maintenance Programs through Statistical Analysis," Boeing AeroMagazine (43:3), pp. 12-15.

Melville, N., Kraemer, K., and Gurbaxani, V. 2004. "Review: Information Technology and Organizational Performance: An Integrative Model of IT Business Value," MIS Quarterly (28:2), pp. 283-322.

Mithas, S., Ramasubbu, N., and Sambamurthy, V. 2011. "How Information Management Capability Influences Firm Performance," MIS Quarterly (35:1), pp. 237-256.

Nazir, S., and Pinsonneault, A. 2012. "IT and Firm Agility: An Electronic Integration Perspective," Journal of the Association for Information Systems (13:3), pp. 150-171.

Ndofor, H., Sirmon, D.G., and He, X. 2011. "Firm Resources, Competitive Actions and Performance: Investigating a Mediated Model with Evidence from the in-Vitro Diagnostics Industry," Strategic Management Journal (32:6), pp. 640-657.

Nevo, S., and Wade, M.R. 2010. "The Formation and Value of IT-Enabled Resources: Antecedents and Consequences of Synergistic Relationships," MIS Quarterly (34:1), pp. 163-183.

Newkirk, H.E., Lederer, A.L., and Johnson, A.M. 2008. "Rapid Business and IT Change: Drivers for Strategic Information Systems Planning?," European Journal of Information Systems (17:3), pp. 198218.

Numanoglu, S. 2010. "New Service Requests Application," Boeing AeroMagazine (40:4), pp. 26-28.

Nunnally, J.C. 1978. Psychometric Theory, 2ed. New York: McGraw-Hill.

O'Reilly, C., and Tushman, M. 2008. "Ambidexterity as a Dynamic Capability: Resolving the Innovator's Dilemma," Research in Organizational Behavior (28:1), pp. 185-206.

O'Reilly, C., and Tushman, M. 2011. "Organizational Ambidexterity in Action: How Managers Explore and Exploit," California Management Review (53:4), pp. 5-22.

Overby, E., Bharadwaj, A., and Sambamurthy, V. 2006. "Enterprise Agility and the Enabling Role of Information Technology," European Journal of Information Systems (15:2), pp. 120-131.

Palmer, J.W., and Markus, M.L. 2000. "The Performance Impacts of Quick Response and Strategic Alignment in Specialty Retailing," Information Systems Research (11:3), pp. 241-259.

Parnell, J.A. 2000. "Reframing the Combination Strategy Debate: Defining Forms of Combination," Journal of Applied Management Studies (9:1), pp. 33-54.

Patel, P.C., Messersmith, J.G., and Lepak, D.P. 2013. "Walking the Tightrope: An Assessment of the Relationship between High-Performance Work Systems and Organizational Ambidexterity," Academy of Management Journal (56:5), pp. 1420-1442.

Pavlou, P.A., and El Sawy, O.A. 2006. "From IT Leveraging Competence to Competitive Advantage in Turbulent Environments: The Case of New Product Development," Information Systems Research (17:3), pp. 198-227.

Pavlou, P.A., and El Sawy, O.A. 2011. "Understanding the Elusive Black Box of Dynamic Capabilities," Decision Sciences (42:1), pp. 239-273.

Porter, M.E. 1985. Competitive Advantage: Creating and Sustaining Superior Performance. New York: Free Press.

Powell, T.C., and Dent-Micallef, A. 1997. "Information Technology as Competitive Advantage: The Role of Human, Business, and Technology Resources," Strategic Management Journal (18:5), pp. 375405.

Preacher, K.J., and Hayes, A.F. 2004. "SPSS and SAS Procedures for Estimating Indirect Effects in Simple Mediation Models," Behavior Research Methods (36:4), pp. 717-731.

Preacher, K.J., and Hayes, A.F. 2008. "Asymptotic and Resampling Strategies for Assessing and Comparing Indirect Effects in Multiple Mediator Models," Behavior Research Methods (40:3), pp. 879-891. 
Queiroz, M. 2017. "Mixed Results in Strategic IT Alignment Research: A Synthesis and Empirical Study," European Journal of Information Systems (26:1), pp. 21-36.

Rai, A., Arikan, I., Pye, J., and Tiwana, A. 2015. "Fit and Misfit of Plural Sourcing Strategies and ITEnabled Process Integration Capabilities: Consequences of Firm Performance in the US Electric Utility Industry," MIS Quarterly (39:4), pp. 865-885.

Rai, A., Patnayakuni, R., and Seth, N. 2006. "Firm Performance Impacts of Digitally Enabled Supply Chain Integration Capabilities," MIS Quarterly (30:2), pp. 225-246.

Rai, A., and Tang, X. 2010. "Leveraging IT Capabilities and Competitive Process Capabilities for the Management of Interorganizational Relationship Portfolios," Information Systems Research (21:3), pp. 516-542.

Raisch, S., and Birkinshaw, J. 2008. "Organizational Ambidexterity: Antecedents, Outcomes, and Moderators," Journal of Management (34:3), pp. 375-409.

Ravichandran, T. 2017. "Exploring the Relationships between IT Competence, Innovation Capacity and Organizational Agility," The Journal of Strategic Information Systems (in press).

Ravichandran, T., and Lertwongsatien, C. 2005. "Effect of Information Systems Resources and Capabilities on Firm Performance: A Resource-Based Perspective," Journal of Management Information Systems (21:4), pp. 237-276.

Ray, G., Barney, J.B., and Muhanna, W.A. 2004. "Capabilities, Business Processes, and Competitive Advantage: Choosing the Dependent Variable in Empirical Tests of the Resource-Based View," Strategic Management Journal (25:1), pp. 23-37.

Ray, G., Muhanna, W.A., and Barney, J.B. 2005. "Information Technology and the Performance of the Customer Service Process: A Resource-Based Analysis," MIS Quarterly (29:4), pp. 625-652.

Raykov, T. 1998. "Coefficient Alpha and Composite Reliability with Interrelated Nonhomogeneous Items," Applied Psychological Measurement (22:4), pp. 375-385.

Rettig, C. 2007. "The Trouble with Enterprise Software," MIT Sloan Management Review (49:1), pp. 2127.

Richard, P.J., Coltman, T.R., and Keating, B.W. 2012. "Designing IS Service Strategy: An Information Acceleration Approach," European Journal of Information Systems (21:1), pp. 87-98.

Richardson, S., Kettinger, W.J., Banks, M.S., and Quintana, Y. 2014. "IT and Agility in the Social Enterprise: A Case Study of St Jude Children's Research Hospital's" Cure4kids" IT-Platform for International Outreach," Journal of the Association for Information Systems (15:1), pp. 1-32.

Rindova, V.P., and Kotha, S. 2001. "Continuous "Morphing": Competing through Dynamic Capabilities, Form, and Function," Academy of Management Journal (44:6), pp. 1263-1280.

Ringle, C., Sarstedt, M., and Straub, D. 2012. "A Critical Look at the Use of PLS-SEM in MIS Quarterly," MIS Quarterly (36:1), pp. III-XIV.

Roberts, N., and Grover, V. 2012. "Leveraging Information Technology Infrastructure to Facilitate a Firm's Customer Agility and Competitive Activity: An Empirical Investigation," Journal of Management Information Systems (28:4), pp. 231-270.

Ross, J., Weill, P., and Robertson, D. 2006. Enterprise Architecture as Strategy: Creating a Foundation for Business Execution. Boston, MA: Harvard Business School Press.

Sabherwal, R., and Chan, Y.E. 2001. "Alignment between Business and IS Strategies: A Study of Prospectors, Analyzers, and Defenders," Information Systems Research (12:1), pp. 11-33.

Sambamurthy, V., Bharadwaj, A., and Grover, V. 2003. "Shaping Agility through Digital Options: Reconceptualizing the Role of Information Technology in Contemporary Firms," MIS Quarterly (27:2), pp. 237-263.

Setia, P., Sambamurthy, V., and Closs, D.J. 2008. "Realizing Business Value of Agile IT Applications: Antecedents in the Supply Chain Networks," Information Technology and Management (9:1), pp. 519. 
Setia, P., Venkatesh, V., and Joglekar, S. 2013. "Leveraging Digital Technologies: How Information Quality Leads to Localized Capabilities and Customer Service Performance," MIS Quarterly (37:2), pp. 565-590.

Sharma, R., and Shanks, G. 2011. "The Role of Dynamic Capabilities in Creating Business Value from IS Assets," Americas Conference on Information Systems, Detroit.

Sharma, R., Yetton, P., and Crawford, J. 2009. "Estimating the Effect of Common Method Variance: The Method--Method Pair Technique with an Illustration from TAM Research," MIS Quarterly (33:3), pp. 473-490.

Shinkle, G.A., Kriauciunas, A.P., and Hundley, G. 2013. "Why Pure Strategies May Be Wrong for Transition Economy Firms," Strategic Management Journal (34:10), pp. 1244-1254.

Sirmon, D.G., and Hitt, M. 2009. "Contingencies within Dynamic Managerial Capabilities: Interdependent Effects of Resource Investment and Deployment on Firm Performance," Strategic Management Journal (30:13), pp. 1375-1394.

Sirmon, D.G., Hitt, M.A., and Ireland, R.D. 2007. "Managing Firm Resources in Dynamic Environments to Create Value: Looking inside the Black Box," Academy of Management Review (32:1), pp. 273292.

Sirmon, D.G., Hitt, M.A., Ireland, R.D., and Gilbert, B.A. 2011. "Resource Orchestration to Create Competitive Advantage: Breadth, Depth, and Life Cycle Effects," Journal of Management (37:5), pp. 1390-1412.

Slater, S.F., and Narver, J.C. 1994. "Does Competitive Environment Moderate the Market OrientationPerformance Relationship?," Journal of Marketing (58:1), pp. 46-55.

Smith, W.K., and Lewis, M.W. 2011. "Toward a Theory of Paradox: A Dynamic Equilibrium Model of Organizing," Academy of Management Review (36:2), pp. 381-403.

Smith, W.K., and Tushman, M.L. 2005. "Managing Strategic Contradictions: A Top Management Model for Managing Innovation Streams," Organization Science (16:5), pp. 522-536.

Sobel, M.E. 1982. "Asymptotic Confidence Intervals for Indirect Effects in Structural Equation Models," in Sociological Methodology, S. Leinhardt (ed.). Washington, DC: American Sociological Association, pp. 290-312.

Spanos, Y.E., Zaralis, G., and Lioukas, S. 2004. "Strategy and Industry Effects on Profitability: Evidence from Greece," Strategic Management Journal (25:2), pp. 139-165.

Stabell, C.B., and Fjeldstad, Ø.D. 1998. "Configuring Value for Competitive Advantage: On Chains, Shops, and Networks," Strategic Management Journal (19:5), pp. 413-437.

Subramani, M. 2004. "How Do Suppliers Benefit from Information Technology Use in Supply Chain Relationships?," MIS Quarterly (28:1), pp. 45-73.

Tallon, P.P. 2007. "Does IT Pay to Focus? An Analysis of IT Business Value under Single and MultiFocused Business Strategies," The Journal of Strategic Information Systems (16:3), pp. 278-300.

Tallon, P.P. 2008. "A Process-Oriented Perspective on the Alignment of Information Technology and Business Strategy," Journal of Management Information Systems (24:3), pp. 227-268.

Tallon, P.P., and Kraemer, K.L. 2007. "Fact or Fiction? A Sensemaking Perspective on the Reality Behind Executives' Perceptions of IT Business Value," Journal of Management Information Systems (24:1), pp. 13-54.

Tallon, P.P., and Pinsonneault, A. 2011. "Competing Perspectives on the Link between Strategic Information Technology Alignment and Organizational Agility: Insights from a Mediation Model," MIS Quarterly (35:2), pp. 463-486.

Tallon, P.P., Queiroz, M., Coltman, T., and Sharma, R. 2016. "Business Process and Information Technology Alignment: Construct Conceptualization, Empirical Illustration, and Directions for Future Research," Journal of the Association for Information Systems (17:9), pp. 555-580.

Tanriverdi, H. 2006. "Performance Effects of Information Technology Synergies in Multibusiness Firms," MIS Quarterly (30:1), pp. 57-77. 
Teece, D.J. 2007. "Explicating Dynamic Capabilities: The Nature and Microfoundations of (Sustainable) Enterprise Performance," Strategic Management Journal (28:1), pp. 1319-1350.

Teece, D.J., Pisano, G., and Shuen, A. 1997. "Dynamic Capabilities and Strategic Management," Strategic Management Journal (18:7), pp. 509-533.

Thornhill, S., and White, R. 2007. "Strategic Purity: A Multi-Industry Evaluation of Pure Vs. Hybrid Business Strategies," Strategic Management Journal (28:5), pp. 553-561.

Treacy, M., and Wiersema, F. 1995. The Discipline of Market Leaders. Addison-Wesley Reading, MA.

Tsai, H.-T., and Bagozzi, R.P. 2014. "Contribution Behavior in Virtual Communities: Cognitive, Emotional, and Social Influences," MIS Quarterly (38:1), pp. 143-163.

Tsai, K.-H., and Yang, S.-Y. 2013. "Firm Innovativeness and Business Performance: The Joint Moderating Effects of Market Turbulence and Competition," Industrial Marketing Management (42:8), pp. 1279-1294.

Tushman, M.L., and O'Reilly, C.A. 1996. "Ambidextrous Organizations: Managing Evolutionary and Revolutionary Change," California Management Review (38:4), pp. 8-29.

Van Oosterhout, M., Waarts, E., and Van Hillegersberg, J. 2006. "Change Factors Requiring Agility and Implications for IT," European Journal of Information Systems (15:2), pp. 132-145.

Venkatraman, N. 1989. "Strategic Orientation of Business Enterprises: The Construct, Dimensionality, and Measurement," Management Science (35:8), pp. 942-962.

Vessey, I., and Ward, K. 2013. "The Dynamics of Sustainable IS Alignment: The Case for IS Adaptivity," Journal of the Association for Information Systems (14:6), pp. 283-311.

Vidgen, R., and Wang, X. 2009. "Coevolving Systems and the Organization of Agile Software Development," Information Systems Research (20:3), pp. 355-376.

Wall, T.D., Michie, J., Patterson, M., Wood, S.J., Sheehan, M., Clegg, C.W., and West, M. 2004. "On the Validity of Subjective Measures of Company Performance," Personnel Psychology (57:1), pp. 95118.

Wang, N., Liang, H., Zhong, W., Xue, Y., and Xiao, J. 2012. "Resource Structuring or Capability Building? An Empirical Study of the Business Value of Information Technology," Journal of Management Information Systems (29:2), pp. 325-367.

Weill, P., and Broadbent, M. 1998. Leveraging the New Infrastructure: How Market Leaders Capitalize on Information Technology. Cambridge, MA: Harvard Business School Press.

Weill, P., Subramani, M., and Broadbent, M. 2002. "Building IT Infrastructure for Strategic Agility," MIT Sloan Management Review (44:1), pp. 57-65.

Weill, P., and Vitale, M. 1999. "Assessing the Health of an Information Systems Applications Portfolio: An Example from Process Manufacturing," MIS Quarterly (23), pp. 601-624.

Weill, P., and Vitale, M. 2002. "What IT Infrastructure Capabilities Are Needed to Implement E-Business Models," MIS Quarterly Executive (1:1), pp. 17-34.

Werts, C., Linn, R., and Jöreskog, K. 1978. "A General Method of Estimating the Reliability of a Composite," Educational and Psychological Measurement (38:2), pp. 933-938.

Winter, S.G. 2000. "The Satisficing Principle in Capability Learning," Strategic Management Journal (21:10), pp. 981-996.

Yetton, P., Henningsson, S., and Bjørn-Andersen, N. 2013. ""Ready to Acquire": The IT Resources Required for a Growth-by-Acquisition Business Strategy," MIS Quarterly Executive (12:1), pp. 1935.

Zhao, X., Lynch, J.G., and Chen, Q. 2010. "Reconsidering Baron and Kenny: Myths and Truths About Mediation Analysis," Journal of Consumer Research (37:2), pp. 197-206. 


\section{APPENDIX A \\ Prior Research on IT capabilities and Performance}

Table A1. Summary of Selected Research on the Performance Impacts of IT Capabilities

\begin{tabular}{|c|c|c|c|}
\hline Study & $\begin{array}{l}\text { IT and Related } \\
\text { Capabilities Construct }\end{array}$ & $\begin{array}{l}\text { Mediating / } \\
\text { Moderating } \\
\text { Construct }\end{array}$ & Summary of Findings \\
\hline $\begin{array}{l}\text { Bharadwaj } \\
(2000)\end{array}$ & $\begin{array}{l}\text { IT capability: } \\
\text { - IT infrastructure; human } \\
\text { IT resources; IT enabled } \\
\text { intangibles }\end{array}$ & n.a & $\begin{array}{l}\text { Superior IT capabilities are } \\
\text { associated with higher profit ratios } \\
\text { and lower cost ratios. }\end{array}$ \\
\hline $\begin{array}{l}\text { Ray et al. } \\
(2005)\end{array}$ & $\begin{array}{l}\text { Technical IT skills; } \\
\text { Generic technologies; } \\
\text { Flexible IT infrastructure }\end{array}$ & $\begin{array}{l}\text { Moderator: } \\
\text { Shared knowledge }\end{array}$ & $\begin{array}{l}\text { Technical IT skills and flexibility of } \\
\text { IT infrastructure do not impact } \\
\text { process performance. Shared } \\
\text { knowledge affects process } \\
\text { performance and moderates the link } \\
\text { between generic technologies and } \\
\text { process performance. }\end{array}$ \\
\hline $\begin{array}{l}\text { Pavlou and El } \\
\text { Sawy (2006) }\end{array}$ & $\begin{array}{l}\text { IT leveraging competence } \\
\text { in new product } \\
\text { development (NPD); NPD } \\
\text { capabilities }\end{array}$ & $\begin{array}{l}\text { Moderator: } \\
\text { Environmental } \\
\text { turbulence } \\
\text { Mediator: } \\
\text { NPD capabilities: } \\
\text { - NPD functional } \\
\text { competences } \\
\text { - NPD dynamic } \\
\text { capabilities* }\end{array}$ & $\begin{array}{l}\text { IT leveraging competence impacts } \\
\text { competitive advantage in NPD } \\
\text { through two mediating links: } \\
\text { functional competencies and } \\
\text { dynamic capabilities. Environmental } \\
\text { turbulence moderates the process by } \\
\text { which IT leveraging competence } \\
\text { affects competitive advantage in } \\
\text { NPD. }\end{array}$ \\
\hline $\begin{array}{l}\text { Fink and } \\
\text { Neumann } \\
(2007)\end{array}$ & $\begin{array}{l}\text { IT personnel capabilities; } \\
\text { IT infrastructure } \\
\text { capabilities }\end{array}$ & $\begin{array}{l}\text { Mediators: } \\
\text { IT-dependent } \\
\text { system agility; } \\
\text { information agility }\end{array}$ & $\begin{array}{l}\text { Technical and behavioral } \\
\text { capabilities of IT personnel affect IT } \\
\text { infrastructure capabilities. In turn, } \\
\text { IT infrastructure capabilities affect } \\
\text { strategic agility directly and also } \\
\text { indirectly via IT-dependent system } \\
\text { and information agility. }\end{array}$ \\
\hline $\begin{array}{l}\text { Kim et al. } \\
(2011)\end{array}$ & $\begin{array}{l}\text { IT capabilities: } \\
\text { - IT management; IT } \\
\text { personnel expertise; IT } \\
\text { infrastructure flexibility } \\
\text { Process-oriented dynamic } \\
\text { capabilities* }\end{array}$ & $\begin{array}{l}\text { Mediator: } \\
\text { Process-oriented } \\
\text { dynamic } \\
\text { capabilities }\end{array}$ & $\begin{array}{l}\text { IT capabilities affect process- } \\
\text { oriented dynamic capabilities, which } \\
\text { in turn affect firm performance. }\end{array}$ \\
\hline $\begin{array}{l}\text { Lu and } \\
\text { Ramamurthy } \\
(2011)\end{array}$ & $\begin{array}{l}\text { IT capability: } \\
\text { - IT infrastructure; IT } \\
\text { business spanning; IT } \\
\text { proactive stance }\end{array}$ & $\begin{array}{l}\text { Moderator: } \\
\text { IT spending }\end{array}$ & $\begin{array}{l}\text { IT capability has a positive effect on } \\
\text { market capitalizing agility and } \\
\text { operational adjustment agility. IT } \\
\text { capability and IT spending jointly } \\
\text { affect operational adjustment agility. }\end{array}$ \\
\hline
\end{tabular}


Roberts and

Grover (2012)

Web-based customer

infrastructure;

Interfunctional

coordination;

Chanel coordination

Chakravarthy et IT competencies

al. (2013)

Chen et al.

(2014)

IT capability:

- IT infrastructure; IT business partnerships;

Business IT strategic

thinking; IT business

process integration; IT

management; External

IT linkage

Lee et al. (2015) IT ambidexterity

Rai et al. (2015) Development of ITEnabled Interfirm Process Integration Capability; Development of ITEnabled Intrafirm Process Integration Capability

This Study
IT application orchestration capability*

Moderators: Analytical ability; Internal IS integration

Moderators: Environmental dynamism; IT competencies

\section{Moderators:} Environmental hostility; Environmental complexity

Mediator: Process agility

\section{Moderator:} Environmental dynamism

\section{Mediator:} Operational ambidexterity

Moderator: Market sourcing intensity

Moderator:

Strategic orientation

Mediator: Process agility
IT infrastructure capabilities facilitate agility. The transparency and communication capabilities provided by IT enable business functions to share information that, combined with complementary coordination mechanisms, allows the firm to quickly respond to customer-based opportunities.

IT competencies affect entrepreneurial and adaptive agility. These effects are moderated by environmental dynamism. In addition, IT competencies facilitate the relationship between agility and performance.

IT capability enhances process agility, which in turn improves firm performance. The effect of IT capability on agility depends on the levels of environmental hostility and environmental complexity.

IT ambidexterity has a positive effect on operational ambidexterity. This effect depends on the level of environmental dynamism. Also, IT ambidexterity has a positive effect on organizational agility via operational ambidexterity.

Developing IT-enabled interfirm and intrafirm process integration capabilities enhances firm performance returns and those returns increase with an increase in market sourcing intensity.

IT application orchestration capability has a positive effect on process agility. Strategic orientation moderates this effect such that the effect is stronger in firms pursuing a differentiation strategy. In addition, IT application orchestration capability improves performance through increased process agility.

Notes: $\mathrm{n} . \mathrm{a}=$ not applicable; $*$ Construct conceived of as a dynamic capability or an element of dynamic capabilities. 


\section{APPENDIX B Non-response Bias and Common Method Bias}

\section{The Potential for Non-Response Bias}

To investigate the potential for non-response bias, we first contacted a random sample of 45 nonrespondent executives (3.8\% of non-response firms). Individuals cited privacy concerns and policies prohibiting participation in academic surveys as their principal reasons for failing to reply. Second, we analyzed our sample using the extrapolation procedure presented in Armstrong and Overton (1977). No significant differences were found between early and late respondents (Wilks' lambda=0.93; $\mathrm{F}=0.61$; $\mathrm{N} / \mathrm{S}$ ), suggesting that non-response bias is not a major concern.

\section{The Potential for Common Method Bias}

We sought to mitigate common method bias by following the recommendations proposed by Podsakoff et al. (2003). They advocate developing the survey instrument in a way that reduces common method bias by offering anonymity, protecting respondent identity, and separating scale items used to measure key constructs with questions relating to other non-critical constructs. We followed these suggestions closely when designing our survey.

In addition, we performed a number of tests for common method bias. First, we applied Harmon's ex post one-factor test (Podsakoff and Organ 1986). No dominant factor emerged in our analysis. However, researchers have argued that this test is relatively insensitive (Podsakoff et al. 2003; Sharma et al. 2009). Recognizing this, we employed Lindell and Whitney's (2001) marker variable test. We chose the "commonality of communication networks" $(\mathrm{CCN})$ across the firm as a post hoc marker variable for the analysis. As a marker variable is theoretically unrelated to the study's principal constructs, the correlations should be very small. High correlations between $\mathrm{CCN}$ and our principal constructs would be an indication of common method bias. The average correlation between the principal constructs and $\mathrm{CCN}$ was low and nonsignificant $(r=0.07)$. None of the significant correlations in our model became insignificant after adjustment and nonsignificant 
correlations remain nonsignificant. While Lindell and Whitney (2001) argue that this test provides evidence against the existence of common method bias, other researchers question the validity of this technique to test for method effects (Podsakoff et al. 2003).

Prior research has also argued that very high correlations between constructs in a study (e.g., $r>$ 0.90) are indicative of common method bias (Bagozzi et al. 1991; Pavlou and El Sawy 2006). Our analysis provides no evidence of extremely high correlations. The highest correlation between constructs in our study is 0.44 . Moreover, archival data (when available) could be used to corroborate self-reported survey data, thus further alleviating concerns with common method bias (Pavlou and El Sawy 2006). As shown in Appendix D, we collected archival performance data and used that data to cross-validate our self-reported measure of performance.

\section{References}

Armstrong, J., and Overton, T. 1977. "Estimating Nonresponse Bias in Mail Surveys," Journal of Marketing Research (14:3), pp. 396-402.

Bagozzi, R.P., Yi, Y., and Phillips, L.W. 1991. "Assessing Construct Validity in Organizational Research," Administrative Science Quarterly (36:1), pp. 421-458.

Lindell, M.K., and Whitney, D.J. 2001. "Accounting for Common Method Variance in Cross-Sectional Research Designs," Journal of Applied Psychology (86:1), pp. 114-121.

Pavlou, P.A., and El Sawy, O.A. 2006. "From IT Leveraging Competence to Competitive Advantage in Turbulent Environments: The Case of New Product Development," Information Systems Research (17:3), pp. 198-227.

Podsakoff, P.M., MacKenzie, S.B., Lee, J.-Y., and Podsakoff, N.P. 2003. "Common Method Biases in Behavioral Research: A Critical Review of the Literature and Recommended Remedies," Journal of Applied Psychology (88:5), pp. 879-903.

Podsakoff, P.M., and Organ, D.W. 1986. "Self-Reports in Organizational Research: Problems and Prospects," Journal of Management (12:4), pp. 531-544.

Sharma, R., Yetton, P., and Crawford, J. 2009. "Estimating the Effect of Common Method Variance: The Method--Method Pair Technique with an Illustration from TAM Research," MIS Quarterly (33:3), pp. 473-490. 


\section{APPENDIX C Survey Items and Constructs}

Performance (1: Strongly disagree; 5: Strongly agree)

Adapted from Powell and Dent-Micallef (1997) and Kim et al (2011).

To what extent do the following statements reflect the current situation in your SBU?

a. We are more profitable than our competitors.

b. Our sales growth exceeds that of our competitors.

c. Our revenue growth exceeds that of our competitors.

d. Our market share growth exceeds that of our competitors.

e. Overall, our performance is better than our competitors.

Agility (1: Strongly disagree; 5: Strongly agree)

Adopted from Tallon and Pinsonneault (2011).

Compared to our three nearest competitors, our SBU can easily and quickly...

a. Respond to changes in aggregate customer demand.

b. Customize a product/service to suit an individual customer.

c. React to new product/service launches in the market.

d. Introduce new pricing schedules in response to changes in competitor's prices.

e. Expand into new regional and/or international markets.

f. Expand or reduce the variety of products/services available for sale.

g. Adopt new technologies to increase the throughput of products/services.

h. Switch suppliers or partners.

IT Orchestration Capability (1: Strongly disagree; 5: Strongly agree)

Relative to major competitors, our SBU can quickly ...

a. Develop IT applications internally.

b. Purchase valuable IT applications from suppliers.

c. Discontinue or decommission less-valuable IT applications.

\section{Strategic Orientation}

Adopted from Tallon (2008).

What is the current strategic business orientation of the SBU? Please allocate 100 points across the three orientations below. Allocate the greatest number of points to whatever orientation best describes this SBU.

Operational excellence (business strategy that emphasizes efficiency and reliability, low cost, and end-to-end supply chain optimization):

Customer intimacy (business strategy that emphasizes flexibility and responsiveness, customer service, and market-place management):

Product leadership (business strategy that emphasizes creativity, product development, time to market, and market communications): 


\section{APPENDIX D \\ Cross-Validation of Agility and Performance Measures with Archival Data}

We sought to cross-validate our self-reported measure of performance with archival firm performance data collected from publicly available data sources. Specifically, we collected data on net profit margin, return on assets (ROA), and return on equity (ROE) from S\&P Compustat for the publicly traded firms in our sample $(\mathrm{N}=61)$. The remaining firms are private and do not disclose financial data or were anonymized by respondents under the rules set by our IRB for collecting survey data. This approach is consistent with existing research that suggests that (1) self-reported data are valid substitutes if archival data are unavailable (Wall et al. 2004; Tallon and Kraemer 2007; Pavlou and El Sawy 2011); and that (2) in cases where archival data is available for a subset of the firms in the sample, that data may be used to perform validation checks (Gibson and Birkinshaw 2004; Pavlou and El Sawy 2006).

We collected data for a three-year period, 2010 to 2012 (the year of the survey), and computed average performance scores as a way to reduce the effects of performance variations over this period. Next, we created a summated scale with the archival performance measures and compared it with the selfreported measure of performance. The result of a correlation analysis shows a significant correlation between the self-reported measure of performance and archival firm performance data $(0.29, p<0.05)$.

We also collected archival data to corroborate our measure of agility. In particular, we collected data on revenues, income, and profit for a three-year period (2011 to 2013). Then, we calculated annual growth rates based on revenues, income, and profit data for 2012 and for the following year. Since agility facilitates responses to new market opportunities and to changes in customer demand, one might see improvements in firm growth rates. We found significant correlations between agility and current growth rate $(0.21, p<0.05)$ and between agility and future growth rate $(0.33, p<0.01)$, which includes a oneyear lag in revenues, net income, and profit margin data.

\section{References}


Gibson, C.B., and Birkinshaw, J. 2004. "The Antecedents, Consequences, and Mediating Role of Organizational Ambidexterity," Academy of Management Journal (47:2), pp. 209-226.

Pavlou, P.A., and El Sawy, O.A. 2006. "From IT Leveraging Competence to Competitive Advantage in Turbulent Environments: The Case of New Product Development," Information Systems Research (17:3), pp. 198-227.

Pavlou, P.A., and El Sawy, O.A. 2011. "Understanding the Elusive Black Box of Dynamic Capabilities," Decision Sciences (42:1), pp. 239-273.

Tallon, P.P., and Kraemer, K.L. 2007. "Fact or Fiction? A Sensemaking Perspective on the Reality Behind Executives' Perceptions of IT Business Value," Journal of Management Information Systems (24:1), pp. 13-54.

Wall, T.D., Michie, J., Patterson, M., Wood, S.J., Sheehan, M., Clegg, C.W., and West, M. 2004. "On the Validity of Subjective Measures of Company Performance," Personnel Psychology (57:1), pp. 95118. 